\title{
17. AN EARLY ALBIAN PALYNOFLORA FROM THE KERGUELEN PLATEAU, SOUTHERN INDIAN OCEAN (LEG 120) ${ }^{1}$
}

\author{
Barbara A.R. Mohr ${ }^{2}$ and Carole T. Gee 2,3
}

\begin{abstract}
A well-preserved, diverse sporomorph flora of over 60 species has been found in Cores $120-750 \mathrm{~B}-12 \mathrm{~W}$ through $-14 \mathrm{R}$ from the Southern Kerguelen Plateau. Analysis of the flora indicates that the terrestrial sediments overlaying the basaltic basement are late Early Cretaceous in age. Ranges of the sporomorphs in other parts of Gondwana and the morphology and paucity of angiosperm pollen grains confine the age of this section to the early to possibly early middle Albian.

The Albian palynomorph assemblages in Hole $750 \mathrm{~B}$ are composed primarily of fern spores and podocarpaceous pollen, and show most similarity to those from southern Australia. Changes in the flora through time reflect the successional vegetation changes on barren volcanic islands, beginning with high percentages of colonizing ferns and maturing into conifer (podocarp) forests. The flora shows some signs of endemism, which may be a result of the isolated position of the Kerguelen Islands during the Early Cretaceous. This endemism is expressed by high percentages of a distinctive monosulcate pollen species Ashmoripollis woodywisei n.sp. of pteridosperm or cycadophytean origin, and by a thick-walled, monosulcate angiosperm pollen species of the genus Clavatipollenites.

The climatic conditions were probably cool to temperate (mean annual temperature approximately $7^{\circ}-12^{\circ} \mathrm{C}$ ) and humid (annual rainfall $>1000 \mathrm{~mm}$ ), analogous to modern Podocarpus-dominated forests in New Zealand and in South American mountain regions.
\end{abstract}

\section{INTRODUCTION}

Reconstruction of the early stages of rifting and plate paleogeography during the breakup of the supercontinent Pangaea in the Late Jurassic and Early Cretaceous are but two of the major goals in understanding Late Mesozoic Southern Hemisphere history. Data from the drill sites of such Deep Sea Drilling Project (DSDP) Legs as 27, 28, and 29 in the Australian sector and 40 and 71 in the Atlantic sector of Antarctica, in addition to continental sections, have been the basis for recent plate reconstructions (e.g., Wilson et al., 1989). To study the early phases of rifting between the Antarctic, South America, Africa, and Australia, Ocean Drilling Program (ODP) Leg 113 (Weddell Sea region), as well as Legs 119 and 120 (Kerguelen Plateau), drilled for Lower Cretaceous sediments at Sites 690, 692, 693 (Barker, Kennett, et al., 1988), 738 (Barron, Larsen, et al., 1989), and 747, 748, 749, and 750 (Schlich, Wise, et al., 1989).

Palynology was useful in dating some of these Upper Jurassic and Lower Cretaceous sections in the following sites: Sites 259,261 , and 263 on Leg 27 (Wiseman and Williams, 1974); Sites 327, 328, and 330 on Leg 36 (Harris, 1976; Hedlund and Beju, 1976); Site 361 on Leg 40 (McLachlan and Pieterse, 1978; Davey, 1978); and Site 511 on Leg 71 (Kotova, 1983). In addition, geographic distribution patterns of certain pollen and spore taxa (e.g., Dettmann and Thomson, 1987) are helpful in understanding Early Cretaceous Southern Hemisphere paleogeography.

Leg 120 drilled Site 750 on the Southern Kerguelen Plateau (Fig. 1), in the South Indian Ocean, approximately $900 \mathrm{~km}$ south of the present-day Polar Front. The primary goal was to recover an expanded Cretaceous section reflecting the early

\footnotetext{
${ }^{1}$ Wise, S. W., Jr., Schlich, R., et al., 1992. Proc. ODP, Sci. Results, 120: College Station, TX (Ocean Drilling Program).

2 ETH-Zürich, Geological Institute, CH-8092 Zürich, Switzerland.

${ }^{3}$ Present address: University of Bonn, Institute of Paleontology, D-5300 Bonn, Germany.
}

tectonic and depositional history of the Southern Kerguelen Plateau. This would provide a better understanding of the timing of the major phases of spreading at Hole 750B.

The deepest sedimentary unit, which overlies basalt at Hole $750 \mathrm{~B}$, is a red to dark gray brown silty claystone with charcoal (e.g., Francis and Coffin, this volume). The sporomorph flora discussed in this study indicates that the age of this terrestrial claystone is early Albian. This study also documents the microflora, reconstructs the paleovegetation and its succession in the vicinity of the Kerguelen Islands, and discusses implications for early angiosperm evolution and phytogeography in southern Gondwana during the AptianAlbian.

\section{Geographic and Geologic Setting}

The Kerguelen Plateau, located in the south-central Indian Ocean between $46^{\circ}$ and $64^{\circ} \mathrm{S}$ (Fig. 1), can be divided into two distinct domains: the Kerguelen-Heard Plateau to the north, and the volcanic Kerguelen, Heard, and McDonald islands and the Southern Kerguelen Plateau to the south (Houtz et al., $1977)$. The southern part $\left(57^{\circ}\right.$ to $\left.64^{\circ} \mathrm{S}\right)$ is deeper, generally lying in water depths between 1500 and $2000 \mathrm{~m}$. It is characterized by several large basement uplifts that result in a remarkable topography with crests and basins. The Raggatt Basin contains the most complete sedimentary sequence south of the Banzare Bank. Multichannel seismic surveys of the Raggatt Basin were first conducted during Australian and French cruises (Colwell et al., 1988). At Site 750, we drilled the total sedimentary sequence and bottomed in basaltic basement with the primary goal of calibrating the seismic stratigraphy.

\section{Site $\mathbf{7 5 0}$}

Holes $750 \mathrm{~A}$ and $750 \mathrm{~B}$ were drilled in the eastern part of the Raggatt Basin (approximately $57^{\circ} 36^{\prime} \mathrm{S}, 81^{\circ} 15^{\prime} \mathrm{E}$ and water depth to $2030.5 \mathrm{~m}$ ) (Fig. 1). In these drill holes, below a $40-\mathrm{cm}$ layer of Pleistocene to lower Pliocene diatom ooze (Unit I), $360 \mathrm{~m}$ of white nannofossil ooze, chalk, and chert of 


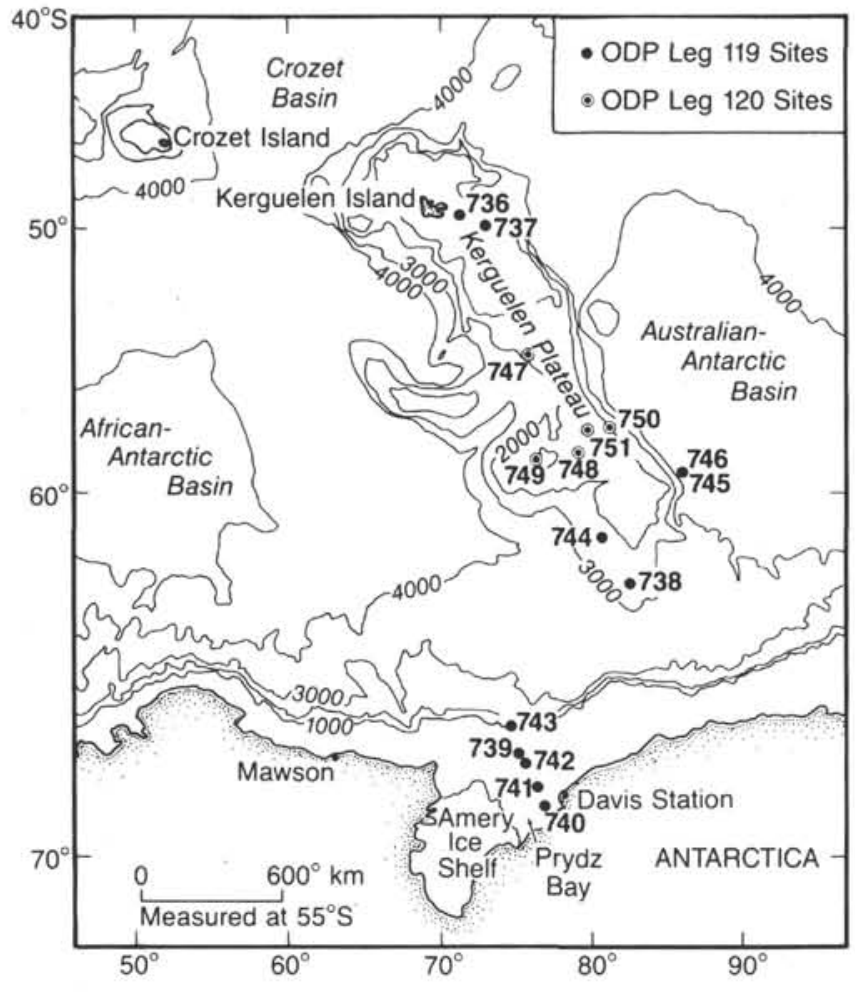

Figure 1. Location of Site 750 in the Raggatt Basin, Kerguelen Plateau.

middle Eocene to Maestrichtian age were cored (Unit II). Figure 2 shows the lower part of Hole $750 \mathrm{~B}$, which encountered the lower part of sedimentary Units III and IV, and the basaltic basement. Unit III consists of pale green to green gray chalks and chert. Limestones with dark bands, traces of molluscs, inoceramids, and wood were recovered in the lower part of Subunit IIIC at depths of 595-623 m below seafloor (mbsf). Unit III is dated as early Santonian to early Maestrichtian according to the nannofossils present (Watkins et al., this volume), in the lower part perhaps Turonian and (or) Cenomanian according to the foraminifers (and dinoflagellate cysts).

From 623.5 to 675.5 mbsf (Unit IV), a red brown silty claystone with coal and minor conglomerates was recovered (Fig. 2). The data in this paper were exclusively collected from this sedimentary unit and suggest an early Albian age. Below $675.5 \mathrm{mbsf}$, approximately $35 \mathrm{~m}$ of highly altered plagioclaseclinopyroxene phyric basalt was drilled. The age estimate for the volcanic basement is $144 \pm 1 \mathrm{~m} . \mathrm{y}$. (Aptian), according to Leclaire et al. (1987).

Hole $750 \mathrm{~A}$ was initially drilled with a wash core technique to 423 mbsf (early Maestrichtian); it was then continuously cored down to a total depth of 460 mbsf (Campanian). Hole $750 \mathrm{~B}$ was initially drilled with spot coring (rotary and wash cores) to 488.5 mbsf (Campanian); the Cretaceous sequence below this level was then sampled. In the wash core technique, a high pressure water jet washes down through the sediment column; as only a few chips of sediment remain in the core barrel, they may come from anywhere within the washed interval. Thus, Cores $120-750 \mathrm{~B}-12 \mathrm{~W}$ to $-14 \mathrm{R}$ contain sediment taken at $20-30-\mathrm{m}$ intervals.

\footnotetext{
${ }^{1}$ The age estimate for the volcanic basement is according to Leclaire et al. (1987) $114 \pm 1$ m.y. (Aptian).
}

\section{MATERIAL AND METHODS}

Lower Cretaceous sediments in Cores 120-750B-12W through $-14 \mathrm{R}$ are composed of a broad range of terrigenous claystones and siltstones with some sandy or conglomeratic intervals. An abundance of carbonized wood fragments was noted in the shipboard report (Schlich, Wise, et al., 1989), which are considered to be of gymnospermaceous origin by Francis and Coffin (this volume). Coarse authigenic siderite and pyrite grains and concretions also were observed. Analysis of the plastic reddish brown, silty claystone indicates that it consists primarily of kaolinite, with up to $25 \%$ siderite, $20 \%$ opaque material, $6 \%$ pyrite, and $20 \%$ altered grains that may have been derived from the altered basalt.

Samples from Hole 750B were processed using standard processing techniques for palynomorphs, in addition to sieving with a $15-\mu \mathrm{m}$ sieve. Smear slides using glycerine jelly were made to examine the kerogen and palynomorphs. For taxonomic determination and photographic documentation, additional single grain slides were made. ODP localities and slide numbers of the figured specimens are given in the plate captions. If a sporomorph was found in a smear slide, its coordinates are given; this refers to Nikon Microscope "Microphot FX," No. 1020-1219. The slides are deposited at the Geological Institute of the ETH (Swiss Federal Institute of Technology) in Zürich. Scanning electron microscope (SEM) pictures were made with a Hitachi S-2300.

\section{RESULTS}

\section{Kerogen Analysis}

About $70 \%$ of the organic particles from lithologic Unit IV (Cores 120-750B-12W through -14R) consist of welldefined, undegraded plant debris, including cuticles and wood fragments such as tracheid fragments (Plate 1), and can thus be classified as structured terrestrial palynodebris. About $30 \%$ of the organic debris is finely shredded or amorphous. Except for a very small amount of dinocyst debris $(<1 \%)$ in Sample 120-750B-12W-CC, which is most likely contamination from the section above (see discussion "Site 750" section, this chapter), the sediment contains exclusively spores and pollen, usually in rather high frequencies (Table 1). According to Habib's $(1979,1982)$ classification scheme of palynodebris, the association belongs to the exinitic facies. The organic matter of Sample 120-750B$11 \mathrm{~W}-\mathrm{CC}$ (lithologic Unit III) is mostly of marine origin (over $90 \%$ ), with well-preserved dinocysts and acritarchs (Table 1) and a high amount of amorphous organic matter. The thermal alteration of the phytoclasts and palynomorphs is generally low, with the thermal alteration index (TAI) $<2$ (coloration according to Traverse, 1988). Thus, the organic material is still immature.

\section{The Palynoflora}

The microflora of Hole 750B (Samples 120-750B-11W-CC through -14R-CC) is composed of dinoflagellate cysts, spores, pollen, and acritarchs. Marine algal and dinoflagellate cysts were found only in Samples 120-750B-11W-CC and 12W-CC, whereas samples from the lower part of the section contained only terrestrial sporomorphs (Table 1). The dinocyst flora in Sample 120-750B-11W-CC is discussed in detail by Mohr and Gee (this volume). It includes such species as Circulodinium colliveri, Litosphaeridium siphoniphorum, Hystrichosphaeropsis galeata, Palaeohystrichophora infusorioides, Disphaeria macropyla, and Odontochitina costata, which indicate a ?Cenomanian to Turonian age. Species indicating younger strata (Turonian to Santonian), such as Isabelidinium 


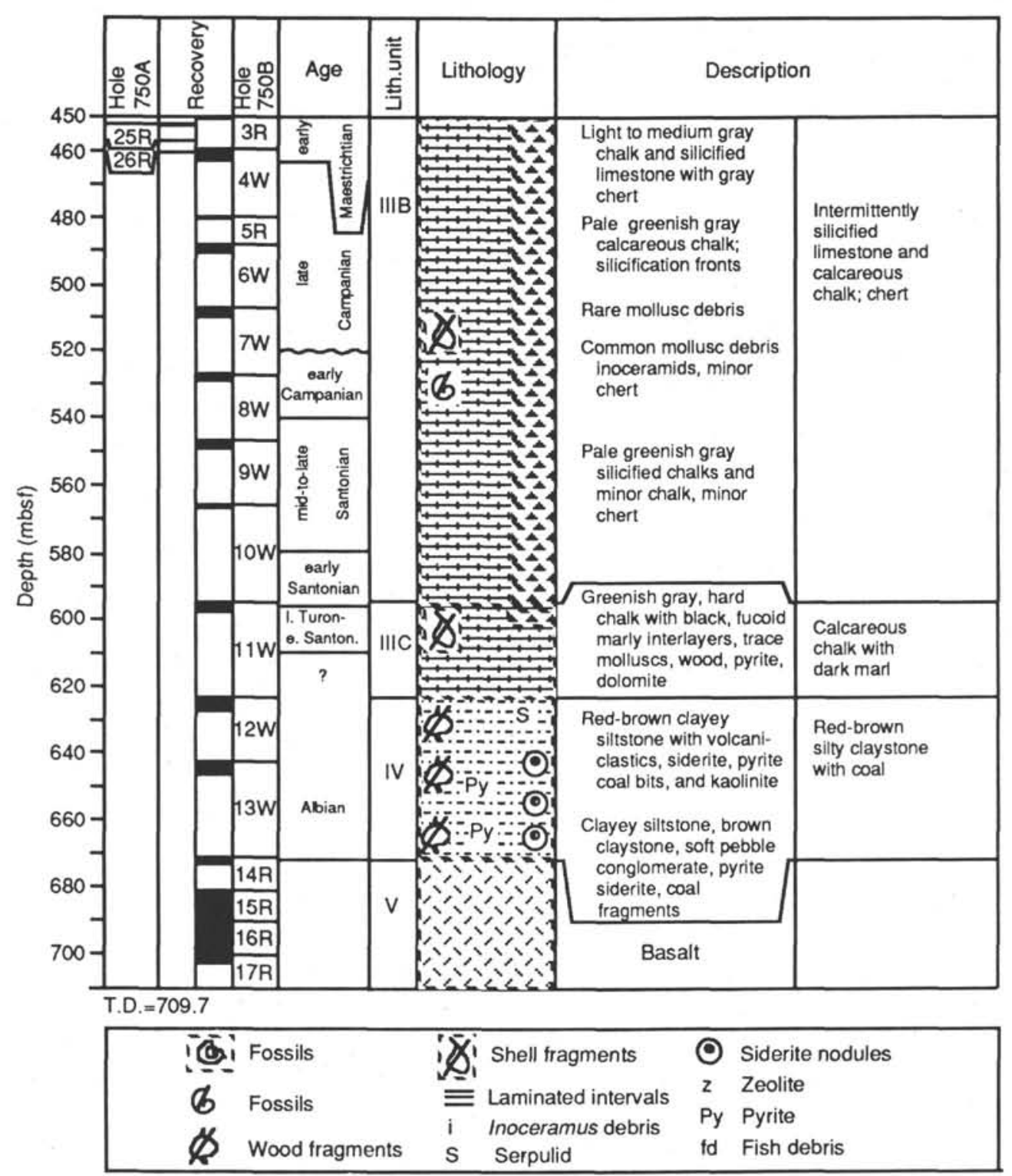

Figure 2. Lithologic summary of Site 750. Palynological samples come exclusively from lithologic Unit IV.

glabrum, were found, perhaps as a result of the coring technique.

This paper centers only on the terrestrial palynomorphs and their implications for mid-Cretaceous biostratigraphy, paleovegetational reconstruction, and paleofloristics. Taxonomic treatment of the sporomorphs is based mainly on the work of Couper (1953), Dettmann (1963), Dettmann and Playford (1968, 1969), Filatoff (1975), Norvick and Burger (1975), Burger (1980), and Backhouse (1988). A complete list of taxonomic references may be found in these papers.

In Appendix A, a list of all the taxa seen in this material is provided; a taxonomic discussion of some of these taxa is given in Appendix B.

\section{Sporomorph Affinities}

The sporomorph flora of Cores 120-750B-14R through $-12 \mathrm{~W}$ comprises the spores of liverworts (Hepatophyta), mosses (Bryophyta), lycophytes (Lycophyta), horsetails (Sphenophyta), and ferns (Pteridophyta), and the pollen of seed ferns (Pteridospermophyta), conifers (Coniferophyta), and angiosperms (Anthophyta). The botanical affinities of the sporomorphs, as determined by their in situ discovery in fossil spore or pollen-bearing organs or in comparison with modern analogs, are listed in Table 2. Much of this information was summarized previously by Dettmann (1963) and Traverse (1988) from the works of others. Our classification scheme follows Bold et al. (1986) for the general systematic framework, Taylor (1981) for fossil taxa, and Tryon and Tryon (1982) for the living ferns.

\section{Liverworts and Mosses (Hepatophyta and Bryophyta)}

The two probable liverwort spore species (Aequitriradites sp. and Foraminisporis dailyi) and the two probable moss spore species (Antulsporites sp. and Stereisporites antiquasporites) are quantitatively minor constituents of the microflora.

\section{Fern Allies and Ferns (Lycophyta and Pteridophyta)}

Trilete spores can belong to lycophytes, as well as ferns. Fern spores, however, are by far dominant in the spore 
Table 1. Preservation of the sporomorphs in lithologic Units III and IV.

\begin{tabular}{|c|c|c|c|}
\hline Core, section, & Depth (mbsf) & Miospores & Dinoflagellates \\
\hline interval $(\mathrm{cm})$ & & & \\
\hline $120-750 \mathrm{~B}-11 \mathrm{~W}-\mathrm{CC}$ & 623.5 & Well preserved, rare & Well preserved, frequent \\
\hline $120-750 \mathrm{~B}-12 \mathrm{~W}-1,39-43$ & 623.9 & Barren & \\
\hline $120-750 \mathrm{~B}-12 \mathrm{~W}-2,116-120$ & 626.6 & Barren & \\
\hline 120-750B-12W-3, 87-89 & 627.3 & Barren & \\
\hline 120-750B-12W-CC & 642.8 & Well preserved, rare & Poorly preserved, rare \\
\hline 120-750B-13W-1, 130-132 & 644.1 & Well preserved, common & \\
\hline 120-750B-13W-2, 90-94 & 645.1 & Well preserved, common & \\
\hline $120-750 B-13 W-3,51-63$ & 646.2 & Excellently preserved, frequent & \\
\hline $120-750 \mathrm{~B}-13 \mathrm{~W}-\mathrm{CC}$ & 671.5 & Well preserved, rare & \\
\hline 120-750B-14R-CC & 681.2 & Well preserved, common & \\
\hline
\end{tabular}

assemblages. In this material, the majority of fern spores can be assigned to either Cyathidites spp. (up to $68 \%$ of total; see Table 3) or Gleicheniidites spp. (up to $54 \%$ of total; see Table 3).

Of the three species of Cyathidites found in the flora, $C$. minor is by far the most common. Clumps composed of 50 or 60 spores are frequently encountered. The botanical affinity of this particular spore species remains uncertain. Although Cyathidites-like spores have recently been extracted and described from the sori of fossil ferns pertaining to the Dicksoniaceae (Van Konijnenburg-van Cittert, 1989), this indistinct type of spore is found today in a number of unrelated fern families (Tryon and Tryon, 1982). It may be possible, however, that the other Cyathidites spp. in the microflora represent dicksoniaceous tree ferns.

Another albeit infrequent spore in the microflora, Cyatheacidites annulatus is a good indicator of tree ferns. The unique spore morphology of Cyatheacidites-type spores suggests affinities with spores of the extant fern Lophosoria (Dettmann, 1986b), which is placed by Tryon and Tryon (1982) in its own family, the Lophosoriaceae. Lophosoria quadripinnata, the single species in the only genus of the family, is primarily a tree fern that lives today in cool, wet, mountain forests in tropical America (Tryon and Tryon, 1982).

The second most common spore type in the microflora include smooth-walled spores with distinctive interradial thickening assigned to Gleicheniidites spp. The spores most likely represent the Gleicheniaceae, a family of tropical to subtropical ferns with a creeping, sprawling habit. As colonizers of nutrient-poor soils, they commonly form thickets in open areas (Tryon and Tryon, 1982; Jones, 1987).

\section{Seed Ferns (Pteridospermaphyta)}

The pollen morphology of the pteridosperms in the microflora varies from monosulcate to monosaccate to bisaccate. The only type of monosulcate pollen in this flora is Ashmoripollis woodywisei, n.sp. This monosulcate pollen is unusual (see Appendix B) in ranging from nonsaccate forms (Plate 3, Figs. 7 and 8 ) to weakly bisaccate forms (Plate 3, Figs. 9 and 10). Although the bisaccate forms are at times reminiscent of podocarpaceous pollen with weakly formed sacci such as Phyllocladus, in the absence of any stronger evidence $A$. woodywisei is allied here with the seed ferns. Affinities to cycadophytes, mainly Bennettitales, cannot be completely ruled out.

Other saccate pollen with probable pteridosperm affinities can be assigned to Alisporites similis, Sulcosaccispora alaticonformis, and Vitreisporites pallidus. All three of these genera have been isolated from male reproductive organs of pteridosperms, although Alisporites-type pollen has been found in conifer cones as well (Traverse, 1988, pp. 235-238). Both Alisporites similis and Vitreisporites pallidus commonly occur together in Southern Hemisphere microfloras, ranging from the Late Jurassic (Harris, 1976; Backhouse, 1988) to the Late Cretaceous (Dettmann and Thomson, 1987). Sulcosaccispora alaticonformis was previously only known from the Triassic and Jurassic strata of Australia (summarized by Filatoff, 1975, p. 76). Its occurrence in the Kerguelen Plateau cores extends its range to the midCretaceous.

\section{Conifers (Coniferophyta)}

The conifer flora is dominated by bisaccate and trisaccate pollen of podocarpaceous affinity, although the nonsaccate pollen of the Araucariaceae (Balmeiopsis spp.), Cheirolepidiaceae (Corollina sp.), and Cupressaceae (Cupressacites sp.) also occur infrequently. One of the most abundant bisaccate species is Podocarpidites ellipticus Cookson (1947), which was first described from lower Tertiary lignites of the Kerguelen Archipelago. Other bisaccate conifer pollen include Podocarpidites marwickii, Rugubivesiculites sp., and cf. Pinuspollenites globosaccus. Podocarpaceous pollen species with both bisaccate and trisaccate forms are Dacrydiumites florinii, Microcachryidites antarcticus, and M. parvus. Pollen of podocarpaceous affinity also include the trisaccate pollen of Podosporites castellanosii and Trichotomosulcites subgranulatus. Almost all of these trisaccate pollen species commonly occur in Jurassic and Cretaceous, and sometimes Early Cenozoic, microfloras of the Southern Hemisphere.

\section{Angiosperms}

Angiosperm pollen are rare $(<2 \%$ of the total sporomorph assemblage). Only two monocolpate pollen species, assigned here to Clavatipollenites hughesii and Clavatipollenites sp. A, occur in the flora. This pollen type has been compared with modern pollen in the family Chloranthaceae by Stuchlik (1984) and Dettmann (1986a), an affinity that is supported by recent investigations of an angiosperm from the Aptian of Australia (Drinnan and Chambers, 1986; Taylor and Hickey, 1990). In one sample (120-750B-13W-1, 130-132 cm), a specimen was discovered that may be a tricolpate pollen grain. The preservation, however, is very poor and makes a positive identification impossible. 
Table 2. Botanical affinity of the sporomorphs.

\begin{tabular}{|c|c|c|}
\hline Sporomorph & Botanical affinity & References \\
\hline $\begin{array}{l}\text { Hepatophyta } \\
\text { Aequitriradites } \\
\text { Nevesisporites dailyi }\end{array}$ & $\begin{array}{l}\text { cf. Sphaerocarpaceae } \\
\text { cf. Phaeoceros bulbiculosus, Nothylas breutelii }\end{array}$ & $\begin{array}{l}\text { Dettmann, } 1963, \text { p. } 92 \\
\text { Dettmann, } 1963, \text { p. } 71\end{array}$ \\
\hline $\begin{array}{l}\text { Bryophyta } \\
\text { Antulsporites } \\
\text { Stereisporites }\end{array}$ & $\begin{array}{l}\text { cf. Sphagnaceae } \\
\text { cf. Sphagnaceae }\end{array}$ & $\begin{array}{l}\text { Filatoff, } 1975 \text {, pp. } 41-3 \\
\text { Filatoff, } 1975, \text { pp. } 36-7 \\
\end{array}$ \\
\hline $\begin{array}{l}\text { Microphyllophyta } \\
\text { Camarozonosporites } \\
\text { Densoisporites } \\
\text { Foveosporites canalis } \\
\text { Neoraistrickia } \\
\text { Retitriletes } \\
\text { Sestrosporites } \\
\end{array}$ & $\begin{array}{l}\text { cf. Lycopodiaceae or Selaginellaceae } \\
\text { cf. Lycopodiaceae or Selaginellaceae } \\
\text { cf. Lycopodium verticillatum group (Lycopodiaceae) } \\
\text { cf. Selaginella, Lycopodium densa } \\
\text { Lycopodium (Lycopodiaceae) } \\
\text { cf. Lycopodium manii, L. laterale (Lycopodiaceae) }\end{array}$ & $\begin{array}{l}\text { Filatoff, } 1975 \text {, pp. } 47-8 \\
\text { Dettmann, } 1963, \text { p. } 84 \text {; Filatoff, } \\
1975, \text { pp. } 46-7 \\
\text { Balme, } 1957 \\
\text { Dettmann, } 1963 \text {, p. } 35 \text {; Filatoff, } \\
\text { 1975, pp. } 51-53 \\
\text { Döring et al in Krutzsch, } 1963 \text {, } \\
\text { pp. } 8-18 \\
\text { Dettmann, } 1963, \text { p. } 66 \\
\end{array}$ \\
\hline $\begin{array}{l}\text { Arthrophyta } \\
\text { Calamospora }\end{array}$ & Equisetites & Traverse, 1988, p. 233 \\
\hline $\begin{array}{l}\text { Pteridophyta } \\
\text { Baculatisporites } \\
\text { Cibotiumspora } \\
\text { Cicatricosisporites } \\
\text { Concavissimisporites } \\
\text { Contignisporites } \\
\text { Cyatheacidites } \\
\text { Cyathidites } \\
\text { Dictyotosporites } \\
\text { Gleicheniidites } \\
\text { Impardecispora } \\
\text { Ischyosporites } \\
\end{array}$ & $\begin{array}{l}\text { cf. Osmunda (Osmundaceae) } \\
\text { cf. Cibotium (Dicksoniaceae) } \\
\text { Ruffordia, Pelletixia (Schizaeaceae) } \\
\text { cf. Cyathea or Dicksonia (Dicksoniaceae), } \\
\text { Lygodium (Schizaeaceae) } \\
\text { cf. Pteridaceae } \\
\text { cf. Lophosoria (Lophosoriaceae) } \\
\text { Coniopteris, Dicksonia, Eboracia, Kylikipteris, } \\
\text { Onychiopsis (Dicksoniaceae) } \\
\text { cf. Cheilantheae (Pteridaceae) } \\
\text { Gleichenia (Gleicheniaceae) } \\
\text { cf. Lygodium, Schizaea (Schizaeaceae) } \\
\text { cf. Dicksoniaceae }\end{array}$ & $\begin{array}{l}\text { Dettmann, } 1963, \text { p. } 34 \\
\text { Chang, } 1965 \\
\text { Traverse, } 1988, \text { p. } 233 \\
\text { Dettmann, } 1963, \text { p. } 30 \\
\text { Filatoff and Price, } 1988 \\
\text { Dettmann, } 1986 \text { b } \\
\text { Traverse, } 1988, \text { p. } 233 ; \text { Van } \\
\text { Konijnenburg-van Cittert, } 1989 \\
\text { Dettmann, } 1986 \text { a } \\
\text { Traverse, } 1988, \text { p. } 233 \\
\text { Venkatachala et al., } 1969 \\
\text { Balme, } 1957 \\
\end{array}$ \\
\hline $\begin{array}{l}\text { Pteridospermophyta } \\
\text { Alisporites } \\
\text { Sulcosaccispora } \\
\text { Vitreisporites }\end{array}$ & $\begin{array}{l}\text { Dicroidium (Corystospermaceae; see also under } \\
\text { Coniferophyta) } \\
\text { Dicroidium (Corystospermaceae) } \\
\text { Caytonanthus, Harrisiothecium (Caytoniales) }\end{array}$ & $\begin{array}{l}\text { Traverse, } 1988, \text { p. } 237 \\
\text { Traverse, } 1988, \text { p. } 238 \\
\end{array}$ \\
\hline $\begin{array}{l}\text { Coniferophyta } \\
\text { Alisporites } \\
\text { Balmeiopsis } \\
\text { Corollina } \\
\text { Cupressacites } \\
\text { Dacrydiumites } \\
\text { Microcachryidites } \\
\text { Podocarpidites } \\
\text { Podosporites } \\
\text { Rugubivesiculites } \\
\text { Trichotomosulcites } \\
\end{array}$ & $\begin{array}{l}\text { Willsiostrobus, Masculostrobus, Comsostrobus, } \\
\text { Lelestrobus (see also under Pteridospermophyta) } \\
\text { Brachyphyllum } \\
\text { primarily Hirmeriella (Cheirolepidiaceae) } \\
\text { cf. Cupressaceae } \\
\text { cf. Dacrydium } \\
\text { cf. Microcachrys } \\
\text { cf. Podocarpus, Dacrydium (Podocarpaceae) } \\
\text { Masculostrobus (Podocarpaceae) } \\
\text { cf. Dacrydium (Podocarpaceae) } \\
\text { Trisacocladus (Podocarpaceae) }\end{array}$ & $\begin{array}{l}\text { Traverse, } 1988, \text { pp. } 235-6 \\
\text { Traverse, } 1988, \text { p. } 238 \\
\text { Traverse, } 1988, \text { p. } 239 \\
\text { Krutzsch, 1971, pp. } 39-42 \\
\text { Cookson and Pike, } 1953 \\
\text { Cookson, } 1947 \\
\text { Cookson, } 1947 \\
\text { Traverse, } 1988 \text {, p. } 237 \\
\text { Pierce, } 1961 \\
\text { Dettmann, } 1986 \text { a } \\
\end{array}$ \\
\hline $\begin{array}{l}\text { Anthophyta } \\
\text { Clavatipollenites }\end{array}$ & cf. Ascarina (Chloranthaceae) & Dettmann, $1986 a$ \\
\hline
\end{tabular}

Notes: Morphological resemblance with living forms is expressed with "cf."; those lacking "cf." were found in situ in sporangia or pollen organs of the fossil plant mentioned. 
Table 3. Percentages of sporomorph types in selected samples from lithologic Unit IV.

\begin{tabular}{|c|c|c|c|c|c|c|c|c|c|c|}
\hline $\begin{array}{l}\text { Depth } \\
\text { (mbsf) }\end{array}$ & $\begin{array}{l}\text { Core-section } \\
\text { interval }(\mathrm{cm})\end{array}$ & 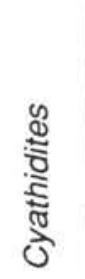 & 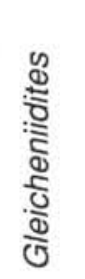 & 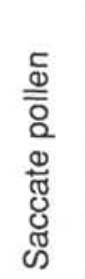 & 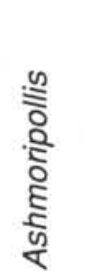 & 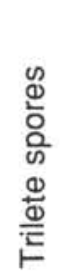 & 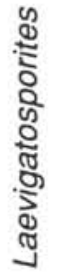 & రั: & 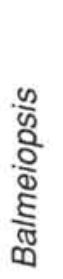 & $\begin{array}{l}\stackrel{0}{E} \\
\frac{5}{\Phi} \\
\frac{0}{0} \\
\frac{0}{0} \\
\frac{\mathrm{E}}{<}\end{array}$ \\
\hline 623.5 & 750B-11W-CC & & & & & & & & & \\
\hline $\begin{array}{l}623.9 \\
626.6 \\
627.3\end{array}$ & $\begin{array}{l}750 \mathrm{~B}-12 \mathrm{~W}-1,39-43 \\
750 \mathrm{~B}-12 \mathrm{~W}-2,116-120 \\
750 \mathrm{~B}-12 \mathrm{~W}-3,87-89\end{array}$ & & & & & & & & & \\
\hline 642.8 & $750 \mathrm{~B}-12 \mathrm{~W}-\mathrm{CC}$ & 28.8 & 14.8 & 36.3 & 0.9 & 18.6 & 0 & 0 & 0 & 0.2 \\
\hline 644.1 & $750 \mathrm{~B}-13 \mathrm{~W}-1,130-132$ & 45.3 & 16.2 & 10.2 & 24.9 & 1.8 & 0.5 & 0.2 & 0.4 & 0.2 \\
\hline 645.1 & 750B-13W-2, 90-94 & 31.5 & 24.1 & 29.2 & 2.7 & 11.7 & 0.8 & 0 & 0.2 & 0 \\
\hline 646.2 & 750B-13W-3, 51-63 & 18.5 & 54.5 & 11.9 & 3.5 & 7.5 & 3.5 & 0 & 0 & 0.2 \\
\hline 671.5 & 750B-13W-CC & 68.7 & 19.7 & 2.4 & 0.8 & 7.9 & 0 & 0 & 0 & 0 \\
\hline 681.2 & 750B-14R-CC & 50.8 & 29.9 & 9.4 & 0.8 & 7 & 0.4 & 0.4 & 0 & 0 \\
\hline
\end{tabular}

\section{Quantitative Analysis and Successional Changes in the Flora}

Samples from Cores 120-750B-13W and -14R were subjected to quantitative analysis. The number of sporomorphs counted varied from 110 to 250 . Based on the total sum, percentages of nine sporomorph groups were calculated (Table 3). When examined graphically (Fig. 3), two results are noteworthy. The first is a roughly inverse relationship between the quantity of fern spores and conifer pollen. The percentage as well as the taxonomic diversity of fern spores is very high in the oldest samples (120-750B-14R-CC and -13W$\mathrm{CC})$, and both generally decrease through time. Conversely, the percentage of conifer pollen (shown in Table 3) increases through time (Samples 120-750B-13W-3, 51-63 cm, through $-12 \mathrm{~W}-\mathrm{CC}$ ).

The changes in relative percentages of spore and pollen types may reflect depositional control or selective preservation. Climatic changes also may have been a major factor, as suggested by Burger (1988) for an Aptian/Albian section in eastern Australia. Alternatively, the changing flora can be interpreted as the result of successional changes in the vegetation on the Kerguelen islands, according to analogous situations today. Following its genesis from volcanic activity, the island was probably colonized by opportunistic plants. The initial vascular plant flora on the Kerguelen islands was dominated by one type of fern, as represented by the many Cyathidites minor spores. Ferns exploit similar niches today. Spicer et al. (1985) observed the pteridoid fern Pityogramma as the primary posteruptional colonizer on volcaniclastic deposits of the Chichonal volcano in Mexico, which erupted in 1982. In all, the entire fern flora was fairly diverse. Through time, the island vegetation increased in diversity and included many more forest-forming plants, such as podocarps. The climax vegetation was likely a podocarp forest with ferns in the understory (see also "Paleovegetational Reconstruction" section, this chapter).

The second interesting point resulting from quantitative analysis is the replacement of bisaccate pollen by Ashmoripollis woodywisei in Sample 120-750B-13W-1, 130-132 cm (Table 3). This floral change may have been the result of short-term climatic changes or facies-related changes that favored the propagation of the Ashmoripollis woodywisei plant during this short time interval.

\section{Biostratigraphy}

The shipboard report states that time-indicative (micro)fossils were not found in lithologic Unit IV (Sections 120-750B$12 \mathrm{~W}-\mathrm{CC}$ through $-14 \mathrm{R}-\mathrm{CC})$. The exact age of this section was unknown; however, it was estimated as being older than Cenomanian. There are biostratigraphically important palynomorphs in the section that indicate a late Early Cretaceous age. Figure 4 shows the ranges of spores and pollen seen in lithologic Unit IV. The ranges of the sporomorphs were compiled from the papers of Backhouse (1988), Dettmann and Thomson (1987), Helby et al. (1987), and Norvick and Burger (1975). We follow the zonation scheme of Helby et al. (1987).

Many spores in the flora, such as Balmeiopsis limbata, $B$. robusta, Foveosporites canalis, and Perotrilites linearis, are not known from strata older than the Valanginian (Backhouse, 1988). Thus, an early Early Cretaceous age for lithologic Unit IV is unlikely.

Impardecispora (Trilobosporites) trioreticulosa, a spore widely distributed in eastern Australia (Cookson and Dettmann, 1958), first occurs in the early to late Aptian Cyclosporites hughesii Zone of Helby et al. (1987) and is also found in younger strata. The monocolpate angiosperm pollen $\mathrm{Cla}$ vatipollenites hughesii ranges from about the latest Aptian to the Coniacian in southern high latitudes. The only species in the Hole 750B section that has not been reported from sediments older than the early-middle Albian (the Coptospora paradoxa Zone of Helby et al., 1987) is Interulobites intraverrucatus.

Contignisporites glebulentus, a common spore in Core $120-750 \mathrm{~B}-13 \mathrm{~W}$, was found by Filatoff and Price (1988) to range from the Bathonian to the Albian, with an acme from the Kimmeridgian to the Neocomian. The morphologically similar species, Contignisporites crenatus, does not occur in postAptian sediments (Filatoff and Price, 1988). According to Dettmann (1986a) in the Australian Gippsland, Otway, and Eromanga basins, Dictyotosporites speciosus extends from the uppermost part of the Crybelosporites stylosus Zone (early Albian) into the basal part of the Coptospora paradoxa Zone (lower part of the middle Albian). In the Antarctic region, 


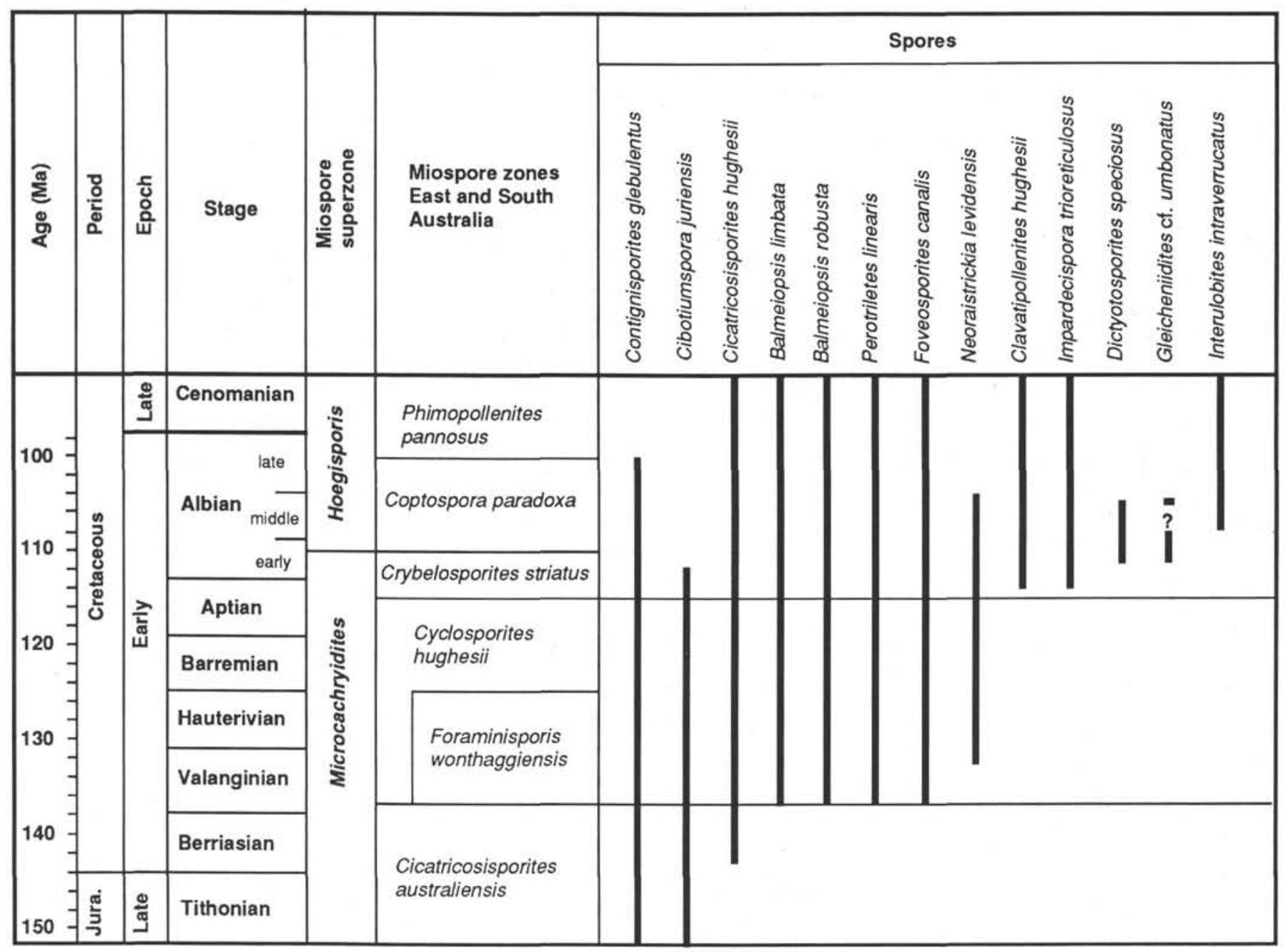

Figure 3. Sporomorph percentages graphically displayed (see Table 3).

Dictyotosporites speciosus is possibly a marker form for the early Albian (Dettmann and Thomson, 1987). The distinctive spore Gleicheniidites sp., cf. G. umbonatus (Bolkhovitina, 1953) Pocock (1970) has been found at another ODP site in the Antarctic region (ODP Leg 113-693A-45R; Mohr and Gee, unpubl. data) in sediments dated with nannofossils (Mutterlose and Wise, 1990) and dinoflagellate cysts (Mohr, 1990) as early Albian.

Cibotiumspora juriensis, which has its last appearance datum (LAD) in the Aptian (Backhouse, 1988), occurs in the lower part of lithologic Unit IV (Sections 120-750B-13W-2 to $-14 \mathrm{~W}-\mathrm{CC}$; see Table 4). However, the presence of Impardecispora trioreticulosus and Dictyotosporites speciosus in this part of the section make an early Albian age likely. In the upper part of lithostratigraphic Unit IV at Hole 750B (Sections 120-750B-12W-CC through 13W-1), where Interulobites intraverrucatus was observed (Table 4), the age is perhaps early middle Albian (lower part of the Coptospora paradoxa Zone of Helby et al., 1987).

Another argument for an early Albian age is the rare occurrence of angiosperm pollen, which is typical for southern high latitudes (Burger, 1981). Only two monocolpate species were observed: Clavatipollenites hughesii and a thick-walled species of Clavatipollenites (Clavatipollenites sp. A; see Appendix B). Both species are found very rarely, making up only $0.2 \%-0.4 \%$ of the total sum of the sporomorphs (Fig. 3). A very poorly preserved ?tricolpate reticulate pollen grain was observed in Sample 120-750B-13W, 130-132 cm. Microfloral assemblages with angiosperm pollen floras of similar low diversity and low frequency are described from southern Victoria, Australia (Dettmann, 1986a), and the Antarctic Peninsula region (Dettmann and Thomson, 1987). Plant megafossils date the southern Australian beds as ?BarremianAptian. The section from the Antarctic Peninsula area (Kotick Point Formation, James Ross Island) is thought to range from Aptian to Albian in age, with the sporomorph-bearing strata in the upper, early Albian part of the section.

\section{Paleovegetational Reconstruction}

One of the striking features of the microflora is the abundance and diversity of spores. Podocarpaceous pollen is also abundant. Evidence of forest-forming plants is indicated by podocarpaceous wood in the form of charcoal found in the same sediments (Francis and Coffin, this volume).

Based on the botanical affinities of the sporomorph flora, the climax vegetation of the Kerguelen Archipelago during the late early Albian can be reconstructed as consisting primarily of podocarp forest. Trees similar to modern Podocarpus and Dacrydium most likely made up the main canopy, which may have been over $30 \mathrm{~m}$ high. Other potentially tree-forming plants of the Cheirolepidiaceae and Cupressaceae were only a minor component in the forest. The next story $(5-25 \mathrm{~m})$ 
Table 4. Stratigraphic occurrences of the sporomorphs in lithologic Units III and IV.

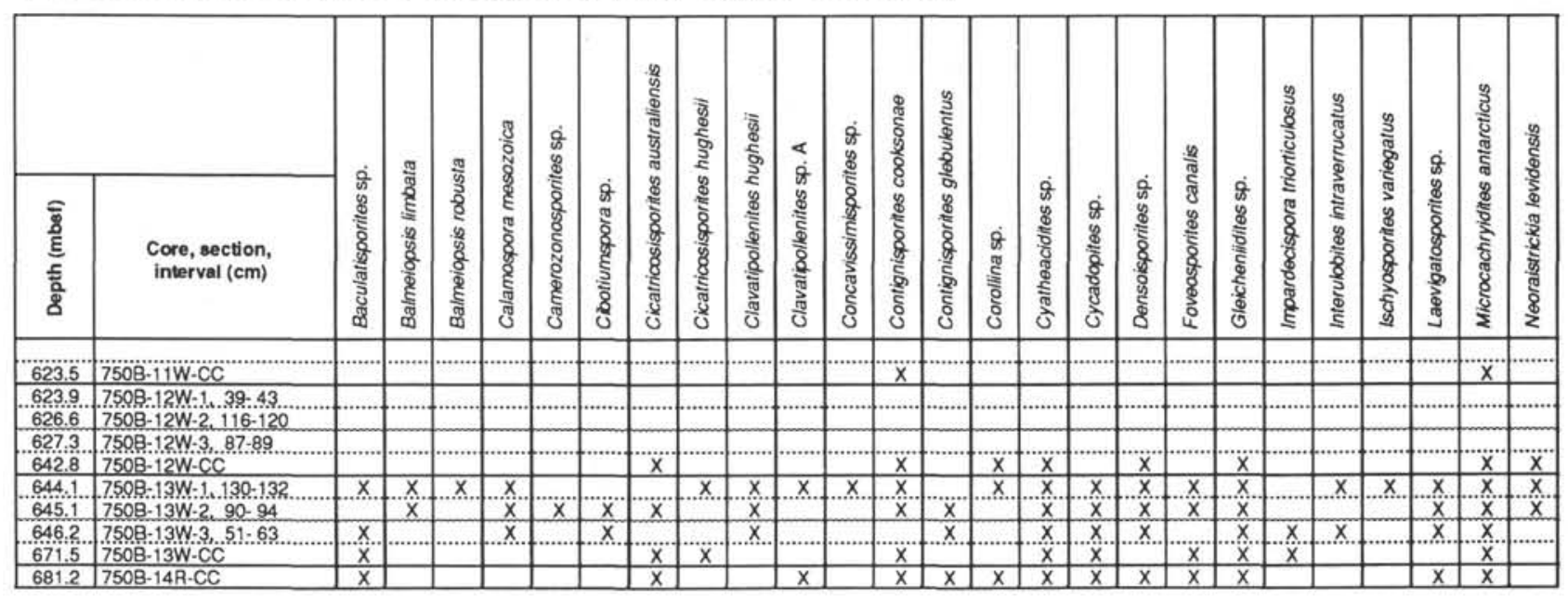

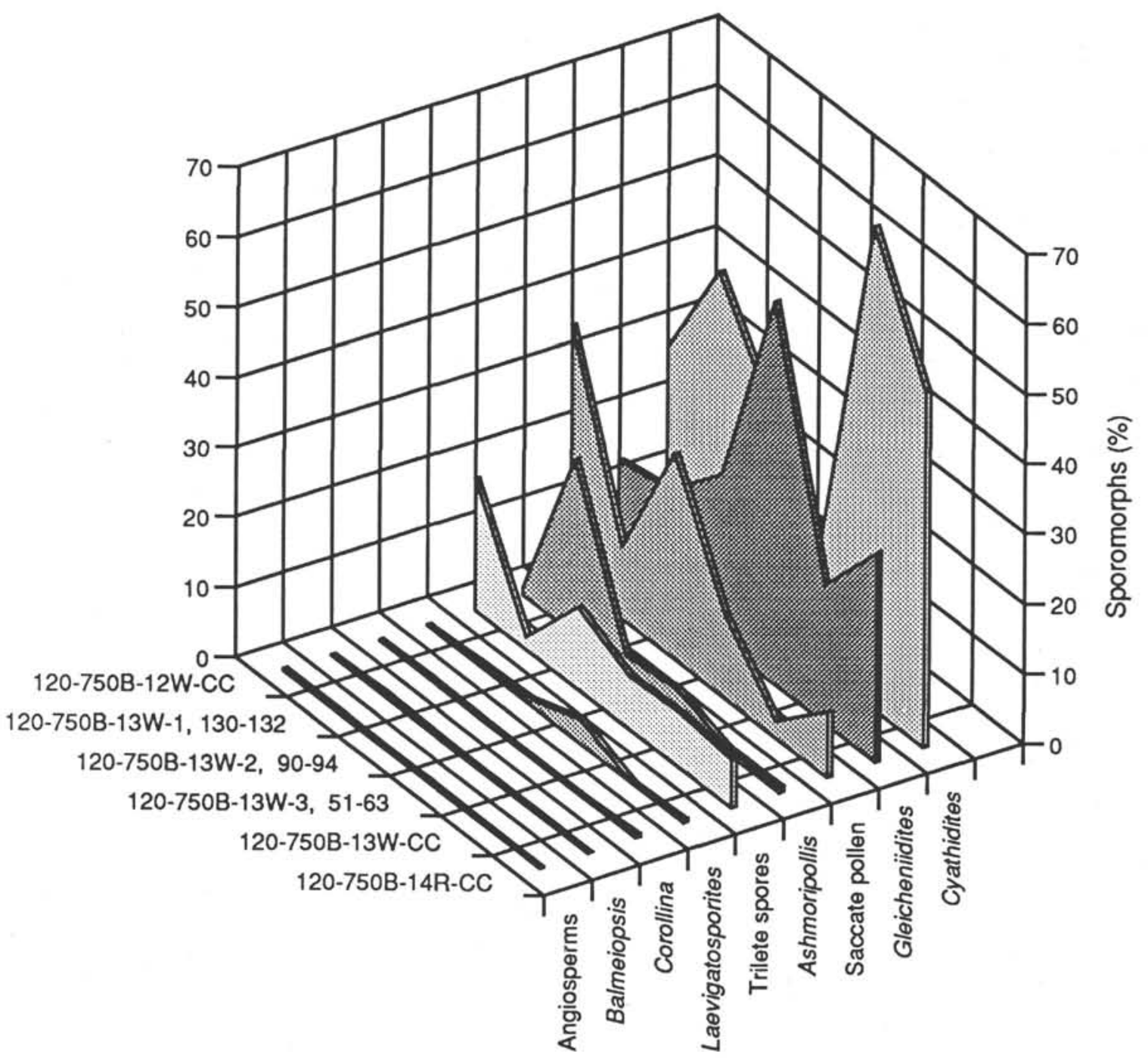

Figure 4. Stratigraphic ranges of the sporomorphs found in lithologic Unit IV. Time scale after Helby et al. (1987). Sporomorph ranges according to Backhouse (1988), Dettmann and Thomson (1987), Helby et al. (1987), and Norvick and Burger (1975). 
Table 4 (continued).

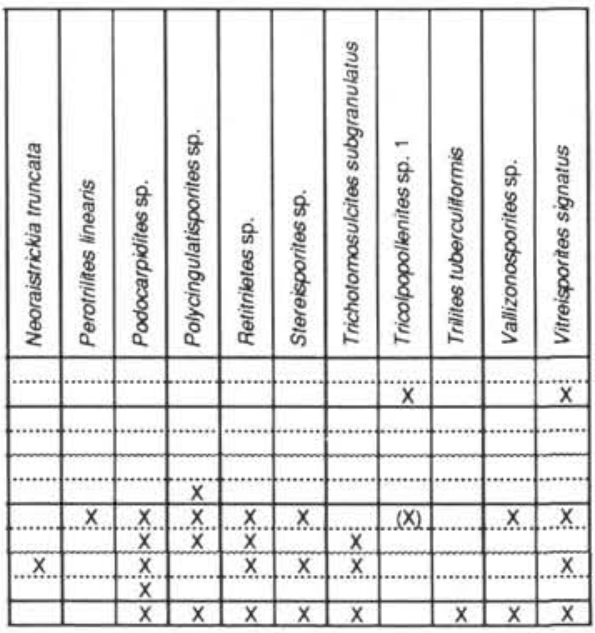

probably consisted of smaller conifers, tree ferns, and seed ferns. Angiosperms, in the form of woody plants or herbs, would have been a rare element. A diversity of terrestrial ferns dominated the forest understory. Mosses, liverworts, lycophytes, and horsetails probably preferred the moister and more humid microenvironments.

The reconstruction of a podocarp-dominated forest as the climax vegetation is in accordance with the floras known from the southern continents during the mid-Cretaceous, particularly in comparison with the paleovegetation of Antarctica (Truswell, 1989). In the Kerguelen and Antarctic floras, the Cheirolepidiaceae (Corollina sp.) have played a lesser role in the paleovegetation than in other (more northerly) Gondwana floras. These distribution patterns of Corollina sp. are shown by Dettmann (1989) in discussing the biogeographic occurrences of some of the Mesozoic floral elements of Antarctica.

Modern analogs for Podocarpus-dominated forests are found in the lowland areas of New Zealand. These conifer and broadleaf forests are multistoried (Wardle et al., 1983), the tallest trees belonging to Podocarpaceae and Cupressaceae. The smaller trees and shrubs in this lowland forest are mostly angiosperms of various families, but tree ferns also play a major role. These forests grow under mild climatic conditions $\left(9^{\circ}-12^{\circ} \mathrm{C}\right.$ annual mean temperature) where the mean annual rainfall exceeds $1000 \mathrm{~mm}$. During the Albian a similar climate is hypothesized for the Kerguelen Plateau area.

\section{Paleofloristic Observations}

In its qualitative and quantitative composition, the Hole $750 \mathrm{~B}$ microflora is similar to other Early to mid-Cretaceous floras known from southern Gondwana, particularly those from southern Australia and Antarctica. These floras are also highly diverse in fern spores and include Cyatheacidites spp., Gleicheniidites spp., Cicatricosisporites australiensis, C. ludbrookiae, and Dictyotosporites speciosus. Podocarpaceous pollen is also abundant.

Another characteristic of Early to mid-Cretaceous palynofloras in Antarctica and Australia is the low frequency or absence of the cheirolepidiacean pollen Corollina. For example, the Aptian and Albian microfloras from the Antarctic shelf near Dronning Maud Land (Leg 113; Mohr and Gee, unpubl. data) contains only $15 \%-20 \%$. This contrasts with the abundance of Corollina $(\geq 60 \%)$ commonly found in South American floras (Volkheimer and Salas, 1975).

Another striking feature in southernmost Gondwana floras is the lack of pollen of gnetalean origin (Ephedripites sp.). Although Ephedripites spp. are common in floras of similar age from more northerly sites in South America (Volkheimer and Salas, 1976; Volkheimer et al., 1976), the Falkland Plateau (Harris, 1976; Kotova, 1983), southern Africa (Scott, 1976; McLachlan and Pieterse, 1978), India (Venkatachala and Kar, 1970; Venkatachala and Rawat, 1971; Venkatachala and Sharma, 1974), and eastern Australia (Burger, 1980), the genus is completely absent from floras from the Antarctic Peninsula, Dronning Maud Land, and southern Australia. When plotted on a paleogeographic reconstruction of Gondwana during the mid-Cretaceous (Fig. 5), the southernmost limit of Ephedripites-producing plants appears to be at a paleolatitude of about $60^{\circ} \mathrm{S}$.

In summary, the $750 \mathrm{~B}$ flora is most similar to the midCretaceous floras from the northern Antarctic Peninsula (Dettmann and Thomson, 1987), the shelf off Dronning Maud Land (Mohr and Gee, unpubl. data), southwestern Australia (Backhouse, 1988), and southeastern Australia (Dettmann, 1966, 1986a; Domack et al., 1980). The localities of these floras roughly form a belt around the antarctic pole, varying from about $50^{\circ}$ to $70^{\circ} \mathrm{S}$ in paleolatitude (Fig. 5).

\section{CONCLUSIONS}

As indicated by the sporomorph flora, the ages of Cores $120-750 \mathrm{~B}-12 \mathrm{R}$ through $-14 \mathrm{R}$ recovered by Leg 120 at Site $750 \mathrm{~B}$ on the Southern Kerguelen Plateau is early to possibly early middle Albian. The microflora is highly diverse with an abundance of fern spores and podocarpaceous pollen. Trends in the floral composition of the cores suggest a sequence of vegetational succession, from a barren volcanic island to a pioneer flora of ferns to mature podocarp-dominated forests. Although the Hole 750B flora contains a few endemic elements, in terms of qualitative and quantitative composition, it is most similar to other mid-Cretaceous microfloras from the high latitudes of Gondwana. Site 750B was also likely located within a belt between the paleolatitudes of $50^{\circ}$ and $70^{\circ} \mathrm{S}$ during mid-Cretaceous times. Climatic conditions were cool to temperate $\left(7^{\circ}-12^{\circ} \mathrm{C}\right)$ with high annual rainfall (precipitation over $1000 \mathrm{~mm})$.

\section{ACKNOWLEDGMENTS}

We wish to express our warmest thanks to S. W. Wise, Jr. (Tallahassee), who initiated this study and provided the material that forms the basis of this work. Two reviewers, R. Hedlund (Tulsa, Oklahoma) and G. L. Williams (Dartmouth, Canada) improved the manuscript by providing helpful comments. The samples were processed by A. Leemann (Zürich) and much of the photographic work was done by U. Gerber (Zürich). The drafting of the figures was assisted by D. Lazarus (Zürich) and P. M. Sander (Bonn). This study was supported by the Swiss National Fund, Grant No. 20.5402.87.

\section{REFERENCES}

Archangelsky, S., 1979. Balmeiopsis, nuevonombre generico para el palinomorfo Inaperturopollenites limbatus Balme 1957. Ameghiniana, 14:122-126.

Archangelsky, S., and Gamerro, J. C., 1965. Estudio palinologico de la Formacion Baquero (Cretacico), Provincia de Santa Cruz. I. Ameghiniana, 4:159-171.

1966a. Estudio palinologico de la Formacion Baquero (Cretacico), Provincia de Santa Cruz. II. Ameghiniana, 4:201-209. 1966b. Estudio palinologico de la Formacion Baquero (Cretacico), Provincia de Santa Cruz. III. Ameghiniana, 4:229236.

1966c. Estudio palinologico de la Formacion Baquero (Cretacico), Provincia de Santa Cruz. IV. Ameghiniana, 4:363-373.

Askin, R. A., 1983. Tithonian (uppermost Jurassic)-Barremian (Lower Cretaceous) spores, pollen and microplankton from the South Shetland Islands, Antarctica. In Oliver, R. L., James, P. R., and 
Jago, J. B. (Eds.), Antarctic Earth Sci. Pap. Int. Symp., 4th., $1982,295-297$.

Backhouse, J., 1988. Late Jurassic and Early Cretaceous palynology of the Perth Basin, Western Australia. Bull. Geol. Surv. West. Aust., 135:1-233.

Baldoni, A. M., and Archangelsky, S., 1983. Palinologia de la Formacion Springhill (Cretacico inferior), subsuelo de Argentina y Chile Austral. Rev. Esp. Micropaleontol., 15:47-101.

Balme, B. E., 1957. Spores and pollen grains from the Mesozoic of Western Australia. Tech. Commun. CSIRO Div. Mineral., 25:1-48.

Barker, P. F., Kennett, J. P., et al., 1988. Proc. ODP, Init. Repts., 113: College Station, TX (Ocean Drilling Program).

Barron, J., Larsen, B., et al., 1989. Proc. ODP, Init. Repts., 119; College Station, TX (Ocean Drilling Program).

Bold, H. C., Alexopoulos, C. J., and Delevoryas, T., 1986. Morphology of Plants and Fungi (5th ed.): New York (Harper and Row).

Burger, D., 1980. Palynological studies in the Lower Cretaceous of the Surat Basin, Australia. Bull. Bur. Miner. Resour. Geol. Geophys. Aust., 189:1-106.

1981. Observations on the earliest angiosperm development with special reference to Australia. IV Int. Palynol. Conf. Lucknow (1976-77), 3:418-428.

1988. Early Cretaceous environments in the Eromanga Basin: palynological evidence from GSO Wyandra-1 corehole. Mem. Assoc. Australas. Palaeontol., 5:173-186.

Chang, L. D., 1965. Sur la question de l'importance des complexes sporo-polliniques de la série houille d'Iman dans la partie ouest de la province du Konan. Acta Palaeontol. Sin., 13:160-196.

Colwell, J. B., Coffin, M. F., Pigram, C. J., Davies, H. L., Stagg, H.M.J., and Hill, P. J., 1988. Seismic stratigraphy and evolution of the Raggatt Basin, Southern Kerguelen Plateau. Mar. Pet. Geol., 5:75-81.

Cookson, I. C., 1947. Plant microfossils from the lignites of Kerguelen Archipelago. B. A. N. Z. Antarc. Res. Exped. 1929-1931 Reports, Ser. A, 2:127-142.

Cookson, I. C., and Dettmann, M. E., 1958. Some trilete spores from Upper Mesozoic deposits in the eastern Australian region. Proc. $R$. Soc. Victoria, 70:95-128.

Cookson, I. C., and Pike, K. M., 1953. A contribution to the Tertiary occurrence of the genus Dacrydium in the Australian region. Aust. J. Bot., 1:474-484.

Couper, R. A., 1953. Upper Mesozoic and Cainozoic spores and pollen grains from New Zealand. Bull. N. Z. Geol. Surv. Palaeontol., 22:1-77.

Davey, R. J., 1978. Marine Cretaceous palynology of Site 361, DSDP Leg 40, off southwestern Africa. In Bolli, H. M., Ryan, W.B.F., et al., Init. Repts. DSDP, 40: Washington (U.S. Govt. Printing Office), 883-913.

Denham, C. R., and Scotese, C. R., 1987. Terra Mobilis: A Plate Tectonic Program for the Macintosh (computer program): Austin (Earth in Motion Technologies).

Dettmann, M. E., 1963. Upper Mesozoic microfloras from southeastern Australia. Proc. R. Soc. Victoria, 77:1-148.

1986a. Early Cretaceous palynoflora of subsurface strata correlative with the Koonwarra Fossil Bed, Victoria. Mem. Assoc. Australas. Palaeontol., 3:79-110.

1986b. Significance of the Cretaceous-Tertiary spore genus Cyatheacidites in tracing the origin and migration of Lophosoria (Filicopsida). Spec. Pap. Palaeontol., 35:63-94.

1989. Antarctica: Cretaceous cradle of austral temperate rain forests? In Crame, J. A. (Ed.), Origins and Evolution of the Antarctic Biota. Geol. Soc. Spec. Publ., 47:89-105.

Dettmann, M. E., and Playford, G., 1968. Taxonomy of some Cretaceous spores and pollen grains from Eastern Australia. Proc. R. Soc. Victoria, 81:69-93.

1969. Palynology of the Australian Cretaceous: a review. In Campbell, K.S.W. (Ed.), Stratigraphy and Paleontology: Essays in Honour of Dorothy Hill: Canberra (A.N.U. Press), 174-210.

Dettmann, M. E., and Thomson, M.R.A., 1987. Cretaceous palynomorphs from the James Ross Island area, Antarctica-a pilot study. Bull. Br. Antarct. Surv., 77:13-59.
Domack, E. W., Fairchild, W. W., and Anderson, J. B., 1980. Lower Cretaceous sediment from the East Antarctic continental shelf. Nature, 287:625-626.

Drinnan, A. N., and Chambers, T. C., 1986. Flora of the Lower Cretaceous Koonwarra Fossil Bed (Korumburra Group), South Gippsland, Victoria. Mem. Assoc. Australas. Palaeontol., 3:1-77.

Filatoff, J., 1975. Jurassic palynology of the Perth Basin, Western Australia. Palaeontographica B, 154:1-113.

Filatoff, J., and Price, P. L., 1988. A pteridacean spore lineage in the Australian Mesozoic. Mem. Assoc. Australas. Palaeontol., 5:89124.

Habib, D., 1979. Sedimentary origin of North Atlantic Cretaceous palynofacies. In Talwani, M., Hay, W., and Ryan, W.B.F. (Eds.), Deep Drilling Results in the Atlantic Ocean: Continental Margins and Paleoenvironment. Am. Geophys. Union, 420-437.

1982. Sedimentary supply origin of Cretaceous black shales. In Schlanger, S. O., and Cita, M. B. (Eds.), Nature and Origin of Cretaceous Carbon-rich Facies: New York (Academic Press), 113-127.

Harris, W. K., 1976. Palynology of cores from Deep Sea Drilling Sites 327, 328, and 330, South Atlantic Ocean. In Barker, P. , Dalziel, I.W.D., et al., Init. Repts. DSDP, 36: Washington (U.S. Govt. Printing Office), 761-815.

Hedlund, R. W., and Beju, D., 1976. Stratigraphic palynology of selected Mesozoic samples, DSDP Hole 327A and Site 330. In Barker, P., Dalziel, I.W.D., et al., Init. Repts. DSDP, 36: Washington (U.S. Govt. Printing Office), 817-827.

Helby, R., Morgan, R., and Partridge, A. D., 1987. A palynological zonation of the Australian Mesozoic. In Jell, P. A. (Ed.), Studies in Australian Mesozoic Palynology. Mem. Assoc. Australas. Palaeontol., 4:1-94.

Houtz, R. E., Hayes, D. E., and Markl, R. G., 1977. Kerguelen Plateau bathymetry, sediment distribution, and crustal structure. Mar. Geol., 25:95-130.

Jones, D. L., 1987. Encyclopaedia of Ferns: London (British Museum of Natural History).

Kotova, I. Z., 1983. Palynological study of Upper Jurassic and Lower Cretaceous sediments, Site 511, Deep Sea Drilling Project Leg 71 (Falkland Plateau). In Ludwig, W. J., Krasheninnikov, V. A., et al., Init. Repts. DSDP, 71, Pt. 2: Washington (U.S. Govt. Printing Office), 879-906.

Krutzsch, W., 1963. Atlas der Mittel- und Jungtertiären dispersen Sporen- und Pollen-sowie der Mikroplanktonformen des Nördlichen Mitteleuropas. II. Die Sporen der Anthocerotaceae und der Lycopodiaceae: Berlin (VEB Deutscher Verlag der Wissenschaften).

1971. Atlas der Mittel- und Jungtertiären dispersen Sporenund Pollen-sowie der Mikroplanktonformen des Nördlichen Mitteleuropas. VI. Coniferenpollen: Jena (VEB Gustav Fischer Verlag).

Leclaire, L., Bassias, Y., Denis-Clocchiatti, M., Davies, H. L., Gautier, I., Gensous, B., Giannesini, P. J., Patriat, P., Ségoufin, J., Tesson, M., and Wannesson, J., 1987. Lower Cretaceous basalt and sediments from the Kerguelen Plateau. Geo-Mar. Lett. 7:169-170.

McLachlan, I. R., and Pieterse, E., 1978. Preliminary palynological results: Site 361, Leg 40, Deep Sea Drilling Project. In Bolli, H. M., Ryan, W.B.F., et al., Init. Repts. DSDP, 40: Washington (U.S. Govt. Printing Office), 857-881.

Mohr, B.A.R., 1990. Early Cretaceous palynomorphs from ODP Sites 692 and 693, the Weddell Sea, Antarctica. In Barker, P. F., Kennett, J. P., et al., Proc. ODP, Sci. Results, 113: College Station, TX (Ocean Drilling Program), 449-465.

Mutterlose, J., and Wise, S. W., Jr., 1990. Lower Cretaceous nannofossil biostratigraphy of ODP Leg 113 Holes 692B and 693A, continental slope off East Antarctica, Weddell Sea. In Barker, P. F., Kennett, J. P., et al., Proc. ODP, Sci. Results, 113: College Station, TX (Ocean Drilling Program), 325-351.

Norvick, M. S., and Burger, D., 1975. Palynology of the Cenomanian of Bathurst Island, Northern territory, Australia. Bull. Bur. Miner. Resour. Geol. Geophys., 151:1-169.

Pierce, R. L., 1961. Lower Upper Cretaceous plant microfossils from Minnesota. Bull. Univ. Minn. Geol. Surv., 42:1-86. 
Playford, G., Haig, D. W., and Dettmann, M. E., 1975. A midCretaceous microfossil assemblage from the Great Artesian Basin, northwestern Queensland. Neues Jahrb. Geol. Palaeontol. Abh., 149:333-362.

Pocock, S.A.J., 1970. Palynology of the Jurassic sediments of western Canada. 1. Terrestrial species. Palaeontographica B, 130:12-136.

Praglowski, J., and Punt, W., 1973. An elucidation of the microreticulate structure of the exine. Grana, 13:45-50.

Schlich, R., Wise, S. W., Jr., et al., 1989. Proc. ODP, Init. Repts., 120: College Station, TX (Ocean Drilling Program).

Scott, L., 1976. Palynology of Lower Cretaceous deposits from the Algo Basin (Republic of South Africa). Pollen et Spores, 19:563-609.

Sharma, K. D., Jain, A. K., and Venkatachala, B. S., 1977. Palynology of the Early Cretaceous sediments from the subsurface of Godavari-Krishna Basin, Andhra Pradesh, south India. Proc. 4th Coll. Indian Micropalaeontol. Stratigr., 110-121.

Singh, H. P., 1966. Reappraisal of the mioflora from the Jalapur Series of India with remarks on the age of the beds. Palaeobotanist, 15:87-92.

Spicer, R. A., Burnham, R. J., Grant, P., and Glicken, H., 1985. Pityogramma calomelanos, the primary, post-eruption colonizer of Volcan Chichonal, Chiapas, Mexico. Am. Fern J., 75:1-5.

Stuchlik, L., 1984. Mortologia de los granos de polen de las Chloranthaceae y Canellaceae Cubanas. Acta Bot. Hung., 30:321-328.

Taylor, D. W., and Hickey, L. J., 1990. An Aptian plant with attached leaves and flowers: implications for angiosperm origin. Science, 247:702-704.

Taylor, T. N., 1981. Paleobotany: An Introduction to Fossil Plant Biology: New York (McGraw-Hill).

Traverse, A., 1988. Paleopalynology: Boston (Unwyn Hyman).

Truswell, E. M., 1989. Cretaceous and Tertiary vegetation of Antarctica-a palynological perspective. In Taylor, T. N., and Taylor, E. L. (Eds.), Antarctic Paleobiology: New York (Springer-Verlag), 71-88.

Tryon, R. M., and Tryon, A. F., 1982. Ferns and Allied Plants: Berlin (Springer-Verlag).

Van Konijnenburg-van Cittert, J.H.A., 1989. Dicksoniaceous spores in situ from the Jurassic of Yorkshire, England. Rev. Palaeobot. Palynol., 61:272-302.

Venkatachala, B. S., and Kar, R. K., 1970. Palynology of the Mesozoic sediments of Kutch, W. India. 10. Palynological zonation of Katrol (Upper Jurassic) and Bhuj (Lower Cretaceous) sediments in Kutch, Gujarat. Palaeobotanist, 18:75-86.

Venkatachala, B. S., Kar, R. K., and Raza, S., 1969. Palynology of the Mesozoic sediments of Kutch, W. India. 3. Morphological study and revision of the spore genus Trilobosporites Pant ex Potonié, 1956. Palaeobotanist, 17:123-126.

Venkatachala, B. S., and Rawat, M. S., 1971. Palynology of Mesozoic sediments of Kutch, West India. 8. A check-list of palynological fossils from Chawad River area and remarks on Asterisporites gen. nov. Palaeobotanist, 19:105-109.

Venkatachala, B. S., and Sharma, K. D., 1974. Palynology of the Cretaceous sediments from the sub-surface of Pondicherry area, Cauvery Basin. New Botanist, 1:170-200.

Volkheimer, W., Quattrocchio, M., Salas, A., and Sepulveda, E., 1976. Caracterizacion palinologica de formaciones del Jurasico superior y Cretacico inferior de la Cuenca Neuquina (Republica Argentina). Actas Sexto Congr. Geol. Argent., Buenos Aires Asoc. Geol. Argent., 593-603.

Volkheimer, W., and Salas, A., 1975. Die älteste AngiospermenPalynoflora Argentiniens von der Typuslokalität der unterkretazischen Huitrin-Folge des Neuquén Beckens. Neues Jahrb. Geol. Palaeontol. Monatsh., 1975, 7:424-436.

1976. Estudio palinologico de la Formacion Huitrin, Cretacico da la Cuenca Neuquina, en su localidad tipo. Actas Sexto Congr. Geol. Argent. Buenos Aires Asoc. Geol. Argent., 433-456.

Volkheimer, W., and Sepulveda, E., 1976. Biostratigraphische Bedeutung und mikrofloristische Assoziation von Cyclusphaera psilata $\mathrm{n}$. sp., einer Leitform aus der Unterkreide des NeuquenBeckens (Argentinien). Neues Jahrb. Geol. Palaeontol. Monatsh., 1976:97-108.

Wardle, P., Bulfin, M.J.A., and Dugdale, J., 1983. Temperate broadleaved evergreen forests of New Zealand. In Ovington, J. D. (Ed.), Ecosystems of the World (Vol. 10): New York (Elsevier), 33-71.
Wilson, K. M., Rosol, M. J., Hay, W. W., and Harrison, C.G.A., 1989. New model for the tectonic history of West Antarctica: a reappraisal of the fit of Antarctica in Gondwana. Ecologae Geol. Helv., 82:1-35.

Wiseman, J. F., and Williams, A. J., 1974. Palynological investigation of samples from Sites 259, 261, and 263, Leg 27 Deep Sea Drilling Project. In Veevers, J. J., Heirtzler, J. R., et al., Init. Repts. DSDP, 27: Washington (U.S. Govt. Printing Office), 915-924.

Date of initial receipt: 23 March 1990

Date of acceptance: 25 February 1991

Ms 120B-161

\section{APPENDIX A}

\section{LIST OF TAXA}

\section{Cryptogam Spores}

Aequitriradites sp.

Antulsporites sp.

Baculatisporites comaumensis (Cookson, 1953) Potonié, 1956

Calamospora mesozoica Couper, 1958 (Plate 1, Fig. 2)

Camarozonosporites sp. (Plate 1, Fig. 3)

Ceratosporites distalgranulatus (Couper, 1958) Kemp, 1970 (Plate 1, Fig. 4)

Cibotiumspora juriensis (Balme, 1957) Filatoff, 1975 (Plate 5, Fig. 5)

Cicatricosisporites hughesii Dettmann, 1963 (Plate 1, Fig. 6)

Cicatricosisporites $\mathrm{sp}$.

Concavissimisporites infirmus (Balme, 1957) Backhouse, 1988 (Plate 1, Fig. 7)

Contignisporites cooksonae (Balme, 1957) Dettmann, 1963 (Plate 1, Fig. 8)

Contignisporites glebulentus (Dettmann, 1963) Filatoff and Price, 1988 (Plate 1, Fig. 9)

Cyatheacidites annulatus Cookson 1947, ex Potonié, 1956 (Plate 1, Fig. 10)

Cyathidites asper (Bolkhovitina, 1953) Dettmann, 1963 (Plate 2, Fig. 1)

Cyathidites minor Couper, 1953 (Plate 2, Fig. 2)

Cyathidites sp.

Densoisporites velatus (Weyland and Krieger, 1953) Dettmann, 1963 (Plate 2, Fig. 3)

Dictyotosporites complex Cookson and Dettmann, 1958 (Plate 2, Fig. 4)

Dictyotosporites speciosus Cookson and Dettmann, 1958 (Plate 2, Fig. 5)

Foveosporites canalis Balme, 1957 (Plate 2, Fig. 6)

Gleicheniidites cercinidites (Cookson, 1953) Dettmann, 1963 (Plate 2, Fig. 7)

Gleicheniidites sp., cf. G. umbonatus (Bolkhovitina, 1953) Pocock, 1970 (Plate 2, Figs. 8 and 9)

Impardecispora trioreticulosus (Cookson and Dettmann, 1958) Venkatachala, Kar and Raza, 1969 (Plate 2, Fig. 10)

Interulobites intraverrucatus Brenner, 1963 (Plate 2, Fig. 11)

Ischyosporites variegatus (Couper, 1958) Schulz, 1967

Laevigatosporites belfordii Burger, 1976 (Plate 2, Fig. 12)

Lycopodiacidites asperatus Dettmann, 1963

Matonisporites $\mathrm{sp}$.

Neoraistrickia levidensis (Balme, 1957) Backhouse, 1988

Neoraistrickia truncata (Cookson, 1953) Potonié, 1956 (Plate 2, Fig. 13)

Nevesisporites dailyi (Cookson and Dettmann, 1958) Backhouse, 1988 (Plate 2, Fig. 15)

Ornamentifera minima Norvick and Burger, 1975 (Plate 2, Fig. 14)

Osmundacidites wellmanii Couper, 1953 (Plate 2, Fig. 16)

Perotrilites linearis (Cookson and Dettmann, 1958) Evans, 1968 (Plate 3 , Figs. 1 and 2)

Polycingulatisporites reduncus (Bolkhovitina, 1953) Playford and Dettmann, 1965 (Plate 2, Fig. 17)

Polycingulatisporites clavus (Balme, 1957) Burger, 1980 (Plate 2, Fig. 18)

Retitriletes eminatus (Dettmann, 1963) Srivastava, 1977 (Plate 2, Fig. 19)

Retispora triquetra (Lantz, 1958) Backhouse, 1988 
Sestrosporites pseudoalveolatus (Couper, 1958) Dettmann, 1963 (Plate 3, Fig. 3)

Stereisporites antiquasporites (Wilson and Webster, 1946) Dettmann, 1963 (Plate 3, Fig. 4)

Stoverisporites lunaris (Cookson and Dettmann, 1958) Burger, 1957 Trilites tuberculiformis Cookson, 1947 (Plate 3, Fig. 5)

\section{Pteridosperm Pollen}

Alisporites similis (Balme, 1957) Dettmann, 1963 (Plate 3, Fig. 6)

Ashmoripollis woodywisei n.sp. (Plate 3, Figs. 7-10)

Sulcosaccispora alaticonformis (Malyavkina) de Jersey, 1968 (Plate 3, Fig. 11)

Vitreisporites pallidus (Reissinger, 1950) Nilsson, 1958 emend. de Jersey, 1964 (Plate 3, Fig. 12)

\section{Conifer Pollen}

Balmeiopsis limbata (Balme, 1957) Archangelsky, 1979 (Plate 3, Fig. 13)

Balmeiopsis robusta Backhouse, 1988 (Plate 3, Fig. 14)

Corollina sp. (Plate 4, Fig. 1)

Cupressacites sp. (Plate 4, Fig. 2)

Cyclusphaera psilata Volkheimer and Sepulveda, 1976 (Plate 4, Fig. 3)

Dacrydiumites florinii Cookson and Pike, 1953 (Plate 4, Fig. 4)

Microcachryidites antarcticus Cookson, 1947 emend. Couper, 1953 (Plate 4, Fig. 6)

Microcachryidites parvus Couper, 1960 (Plate 4, Fig. 7)

cf. Pinuspollenites globosaccus (see Filatoff, 1975) (Plate 4, Fig. 8)

Podocarpidites ellipticus Cookson, 1947 (Plate 4, Fig. 9)

Podocarpidites marwickii Couper, 1953 (Plate 4, Fig. 10)

Podosporites castellanosii (Menéndez, 1968) Filatoff, 1975 (Plate 4, Fig. 11)

Rugubivesiculites sp. (Plate 4, Fig. 12)

Trichotomosulcites subgranulatus Couper, 1953 (Plate 4, Fig. 13)

\section{Angiosperm Pollen}

Clavatipollenites hughesii Couper, 1958

Clavatipollenites $\mathrm{sp}$. A

?Tricolpopollenites sp.

\section{APPENDIX B}

\section{TAXONOMIC NOTES}

Gleicheniidites $\mathrm{sp}$.

\section{cf. G. umbonatus (Bolkhovitina, 1953) Pocock (1970)}

Plate 2, Figure 7

Description. Amb convex-triangular, laesurae simple and extending as straight slits to amb. Laesurae with raised, parallel sided lips, each lip $1.0-1.5 \mu \mathrm{m}$ wide. Spore diameter about $32-35 \mu \mathrm{m}$, sporoderm generally $2-2.5 \mu \mathrm{m}$ thick but extending to $3.5-4 \mu \mathrm{m}$ at the edges.

Discussion. A similar, albeit smaller $(22-25 \mu \mathrm{m})$, spore was described by Pocock (1970) from Jurassic sediments in western Canada. Even though it is unlikely that the Antarctic spore form represents the same biological species as the Canadian spore form, a tentative assignment to Gleicheniidites umbonatus is made until more specimens are available for study. It is quite possible that a new species will be recognized for this form once more is known about its size variation and wall structure.
Occurrence. A single example of this spore was encountered in Sample $120-750 \mathrm{~B}-13 \mathrm{~W}-1,130-132 \mathrm{~cm}$. Identical spores were found in a sample from the Weddell Sea area (Sample 113-693A-45R-1, 99-102 $\mathrm{cm}$ ) that is dated as early Albian by Mohr (1990) and Mutterlose and Wise (1990).

\section{Ashmoripollis woodywisei $\mathrm{n} . \mathrm{sp}$.}

Plate 3, Figures 7-10

Holotype. Plate 3, Figure 7.

Type locality. Kerguelen Plateau, Raggatt Basin (Core 120-750B13W).

Depository of type specimen. Palynological Laboratory, Geological Institute, ETH-Zürich, Switzerland.

Derivation of name. In honor of Dr. Sherwood W. Wise, Jr., known by the nickname "Woody," for his significant contributions to Antarctic micropaleontology.

Sample size. Over 100 specimens.

Diagnosis. Pollen with small sacci that are reduced or have slightly inflated protrusions along the sulcus (leptoma). Outline oval to subcircular in equatorial view, with the polar axis (parallel to colpus) usually slightly longer than the equatorial axis. Exine finely intrareticulate and granulate. Small sacci sometimes absent, at times with a clearly visible intrareticulate structure between the inflated sexine and nexine.

Measurements (10 specimens). Length (parallel to colpus) 23(27.1) $-35 \mu \mathrm{m}$. Width (perpendicular to colpus) 17-(21.7) $-26 \mu \mathrm{m}$. Exine thickness about $1 \mu \mathrm{m}$, nexine thickness about $0.5 \mu \mathrm{m}$, sexine thickness about $0.5 \mu \mathrm{m}$, luminae of the internal reticulum about 0.2 $\mu \mathrm{m}$ in diameter, height of the granulae $0.1 \mu \mathrm{m}$.

Comments. This species encompasses both nonsaccate and bisaccate forms, although all grains have a single sulcus. Sometimes the grain is clearly nonsaccate, whereas in other specimens small distinct bladders are present, one on either side of the sulcus. The sacci are generally the same size on a single pollen grain, but they vary in size between individuals. Thus, there is a morphologic gradation in $A$. woodywisei ranging from nonsaccate to weakly saccate to clearly saccate.

Comparison. Ashmoripollis woodywisei primarily differs from $A$. reducta Helby et al. (1987) in being smaller. In addition, the protrusions of $A$. woodywisei are found exclusively along the edges of the sulcus-like leptoma, unlike those of $A$. reducta, which are in a more lateral position.

Occurrence. Ashmoripollis woodywisei is restricted to the Albian of the Kerguelen Plateau. The holotype and isotypes all come from Core 120-750B-13W.

Botanical affinity. Most likely pteridospermous, perhaps derived from Bennettitales.

\section{Clavatipollenites sp. A \\ Plate 4, Figures 14-16}

Comments. Monocolpate pollen grain with elliptic to subcircular outline. Exine reticulate-tectate. The diameter of the lumina is about $0.1-0.2$ $\mu \mathrm{m}$, the muri are about $0.2-0.3 \mu \mathrm{m}$ in width. Therefore, the pollen is microreticulate according to the definition of Praglowski and Punt (1973).

Measurements (10 specimens). Length: $21-(22)-24 \mu \mathrm{m}$; breadth: 18-(19)-20 $\mu \mathrm{m}$; exine: about 1.0-1.2 $\mu \mathrm{m}$; sexine: 0.6-0.7 $\mu \mathrm{m}$; nexine: $0.4-0.5 \mu \mathrm{m}$.

Botanical affinity. Angiospermous, perhaps related to the Chloranthaceae. 

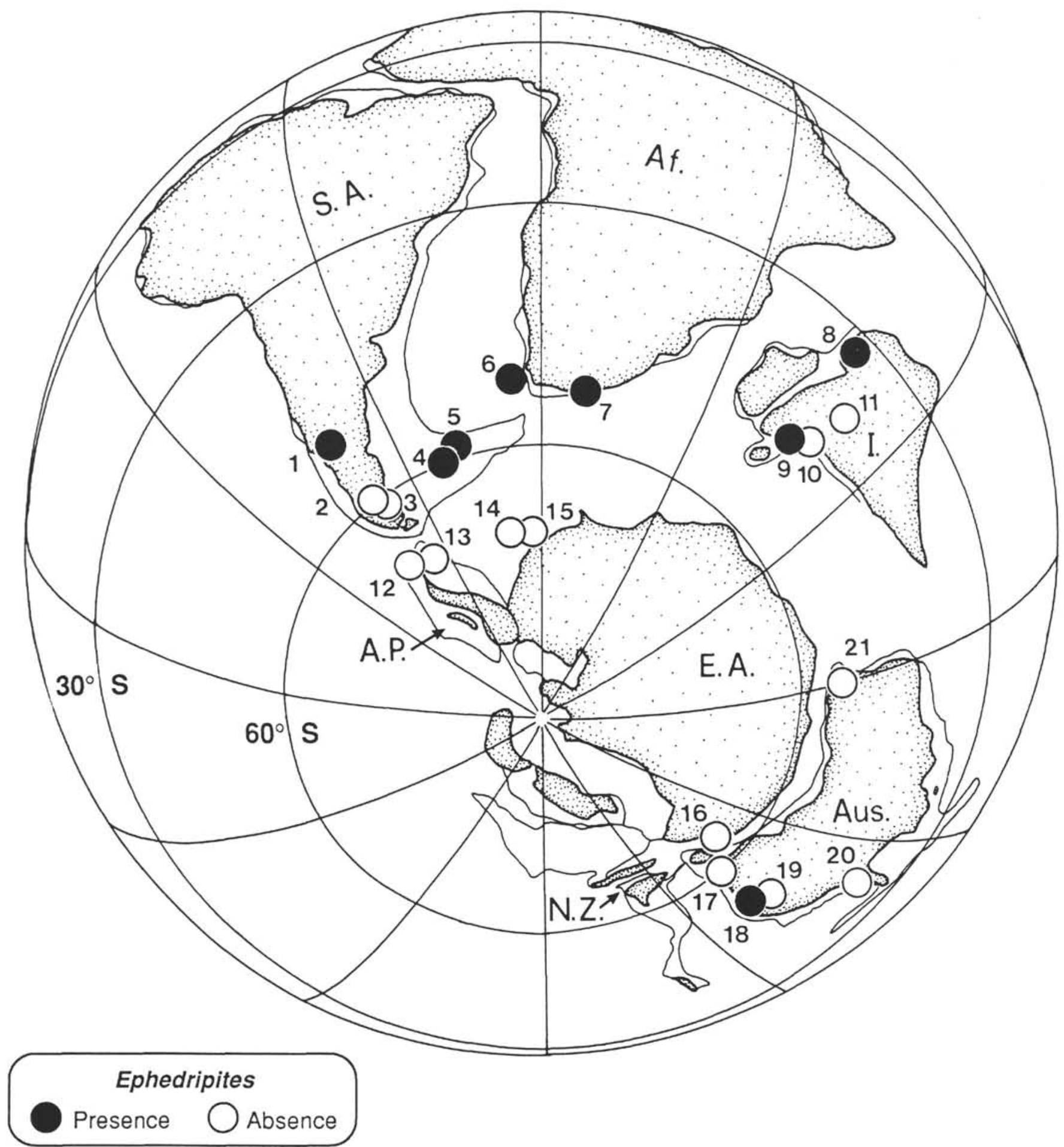

Figure 5. The occurrence of Ephedripites (also known as Equisetosporites) spp. in Early to mid-Cretaceous palynofloras in Gondwana. Note the absence of Ephedripites in paleolatitudes $>60^{\circ} \mathrm{S}$. Plate reconstruction of Gondwana about $110 \mathrm{~m} . \mathrm{y}$. ago (after Denham and Scotese, 1978). Plate abbreviations: S.A. = South America, Af. = Africa, I. = India, A.P. = Antarctic Peninsula, E.A. = East Antarctica, N.Z. = New Zealand, Aus. = Australia. Palynofloras: 1 = Volkheimer and Salas (1976), Volkheimer et al. (1976); 2 = Archangelsky and Gamerro (1965, 1966a, 1966b, 1966c); 3 = Baldoni and Archangelsky (1983); 4 = Harris (1976); 5 = Kotova (1983); 6 = McLachlan and Pieterse (1978); $7=$ Scott (1976); $8=$ Venkatachala and Kar (1970), Venkatachala and Rawat (1971); $9=$ Venkatachala and Sharma (1974); $10=$ Sharma et al. (1977); $11=$ Singh (1966); 12 = Askin (1983); $13=$ Dettmann and Thomson (1987); $14=$ Mohr (1990); $15=$ Mohr and Gee (unpubl. data); $16=$ Domack et al. (1980); 17 = Dettmann (1963, 1986a); $18=$ Burger (1980); $19=$ Burger (1988); $20=$ Playford et al. (1975); $21=$ Backhouse (1988). 

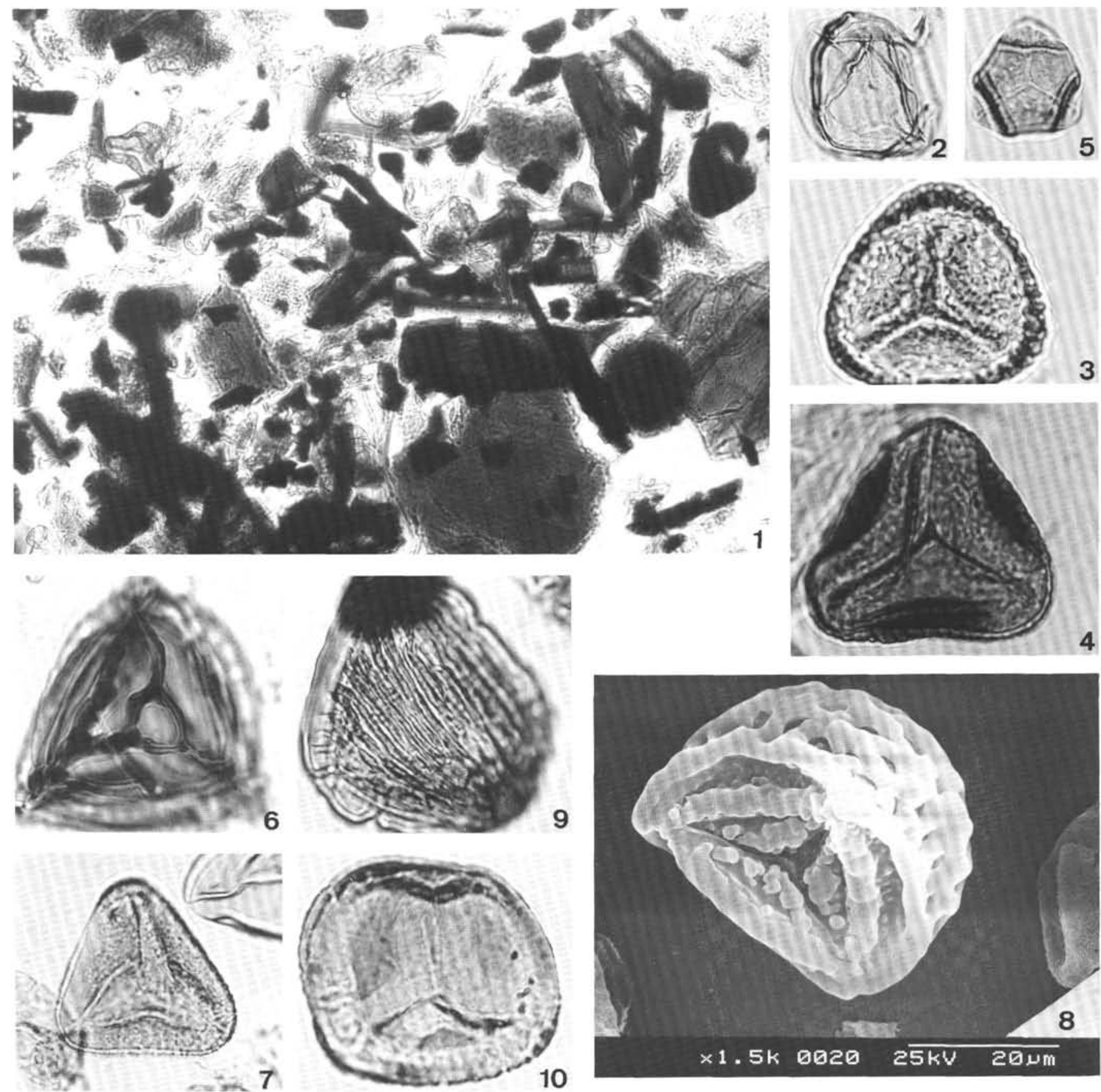

Plate 1. All magnifications $\times 1000$, unless otherwise specified. 1. Kerogen, Sample 120-750B-13W-1, 130-132 cm; sl. 1A, 41/97; $\times 200$. 2 . Calamospora mesozoica Couper, 1958; Sample 120-750B-13W-3, 51-63 cm; sl. 2A, 29.5/85.7. 3. Camarozonosporites sp.; Sample 120-750B13W-2, 90-94 cm; sl. 1A, 36.3/88.5. 4. Ceratosporites distalgranulatus (Couper, 1958) Kemp, 1970; Sample 120-750B-13W-2, 90-94 cm; sl. 3A, 41.5/99.1. 5. Cibotiumspora juriensis (Balme, 1957) Filatoff, 1975; Sample 120-750B-13W-3, 51-63 cm; sl. 2A, 52.5/94.2. 6. Cicatricosisporites hughesii Dettmann, 1963; Sample 120-750B-13W-CC; sl. 1A, 45/94.7. 7. Concavissimisporites infirmus (Balme, 1957) Backhouse, 1988; Sample 120-750B-13W-1, 130-132 cm; sl. 9A, 40.2/90. 8. Contignisporites cooksonae (Balme, 1957) Dettmann, 1963; Sample 120-750B-13W-3, 51-63 cm; $\times 1500$. 9. Contignisporites glebulentus (Dettmann, 1963) Filatoff and Price, 1988; Sample 120-750B-13W-3, 51-63 cm; sl. 3A, 31/91.2. 10. Cyatheacidites annulatus Cookson (1947) ex Potonié, 1956; Sample 120-750B-13W-3, 51-63 cm; sl. 2A, 28.3/99.5. 

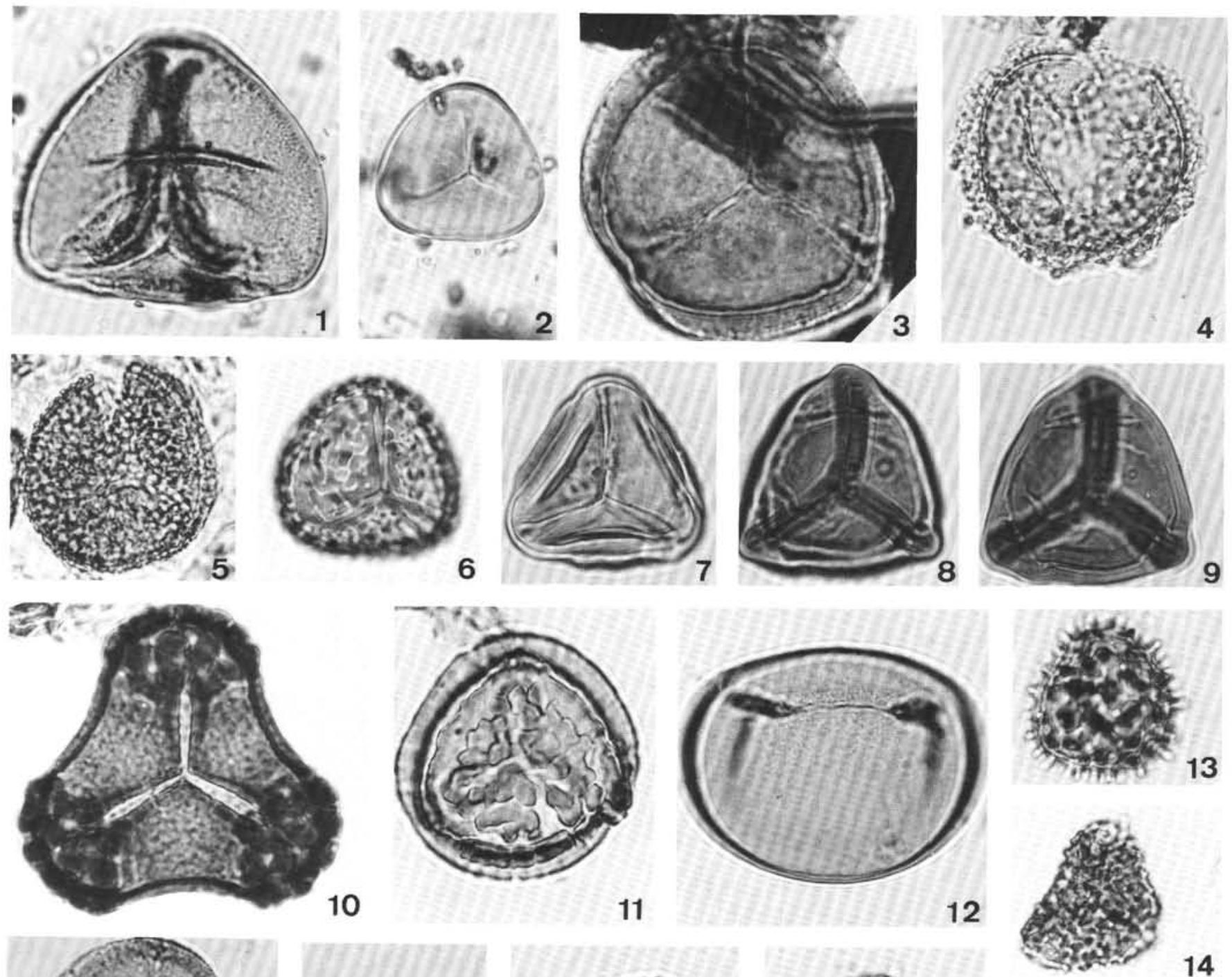

13
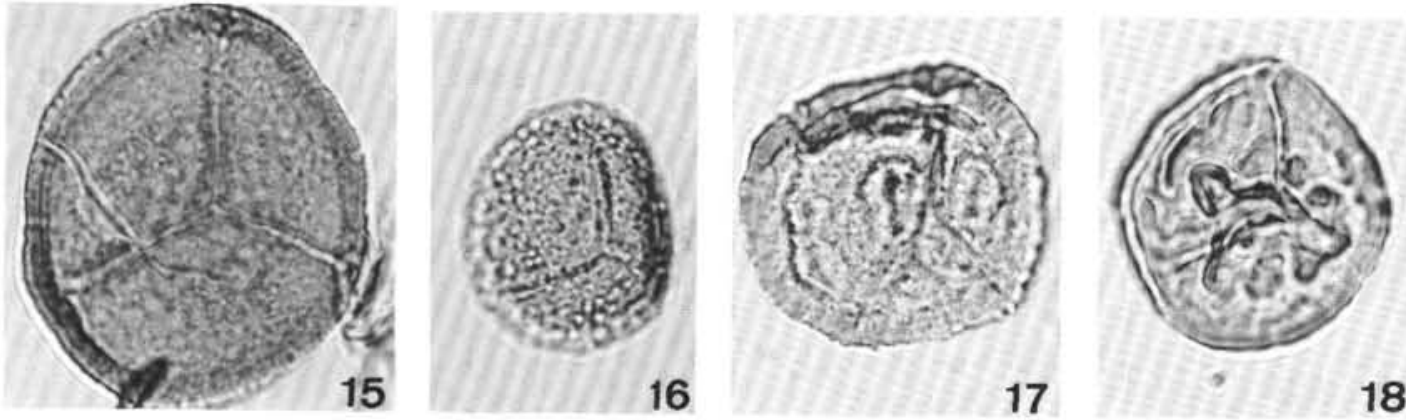

Plate 2. All magnifications $\times 1000$, unless otherwise specified. 1. Cyathidites asper (Bolkhovitina, 1953) Dettmann, 1963; Sample 120-750B-13WCC; sl. 2A, 41.3/96. 2. Cyathidites minor Couper, 1953; Sample 120-750B-14R-CC; sl. 2A, 36/92.2. 3. Densoisporites velatus (Weyland and Krieger, 1953) Dettmann, 1963; Sample 120-750B-13W-1, 130-132 cm; sl. 3A, 33.5/92. 4. Dictyotosporites complex Cookson and Dettmann, 1958; Sample 120-750B-13W-1, 130-132 cm; sl. 8A, 30.5/91.8. 5. Dictyotosporites speciosus Cookson and Dettmann, 1958; Sample 120-750B-13W-1, 130-132 cm; sl. 8A, 48.5/90.5. 6. Foveosporites canalis Balme, 1957; Sample 120-750B-13W-1, 130-132 cm; sl. 7A, 26.2/89. 7. Gleicheniidites cercinidites (Cookson, 1953) Dettmann, 1963; Sample 120-750B-13W-3, 51-63 cm; sl. 2A, 30.5/97.5. 8. cf. Gleicheniidites umbonatus (Bolkhovitina, 1953) Pocock, 1970; proximal focus; Sample 120-750B-13W-1, 130-132 cm; sl. 7A, 43.2/96.5. 9. cf. Gleicheniidites umbonatus (Bolkhovitina, 1953) Pocock, 1970; mid-focus; Sample 120-750B-13W-1, 130-132 cm; sl. 7A, 43.2/96.5. 10. Impardecispora trioreticulosus (Cookson and Dettmann, 1958) Venkatachala, Kar and Raza, 1969; Sample 120-750B-13W-3, 51-63 cm; sl. 2A, 40.8/88.5, ×500. 11. Interulobites intraverrucatus (Brenner, 1963); Sample 120-750B-13W-3, 51-63 cm; sl. 2A, 34.5/95.1. 12. Laevigatosporites belfordii Burger, 1976; Sample 120-750B-13W-3, 51-63 cm; sl. 2A, 27/94.8. 13. Neoraistrickia truncata (Cookson, 1953) Potonié, 1956; Sample 120-750B-13W-3, 51-63 cm; sl. 2A, 31/100. 14. Ornamentifera minima Norvick and Burger, 1975; Sample 120-750B-12W-CC; sl. 17, 38/92. 15. Nevesisporites dailyi (Cookson and Dettmann, 1958) Backhouse, 1988; Sample 120-750B-13W-1, 103-132 cm; sl. 7A, 26.2/89. 16. Osmundacidites wellmanii Couper, 1953; Sample 120-750B-13W-3, 51-63 cm; sl. 2A, 33.5/85. 17. Polycingulatisporites reduncus (Bolkhovitina, 1953) Playford and Dettmann, 1965; Sample 120-750B-13W-1, 130-132 cm; sl. 2A, 43/90. 18. Polycingulatisporites clavus (Balme, 1957) Burger, 1980; Sample 120-750B-12W-CC; sl. 2. 19. Retitriletes eminatus (Dettmann, 1963) Srivastava, 1977; Sample 120-750B-13W-3, 51-63 cm; sl. 2A, 27.2/94. 

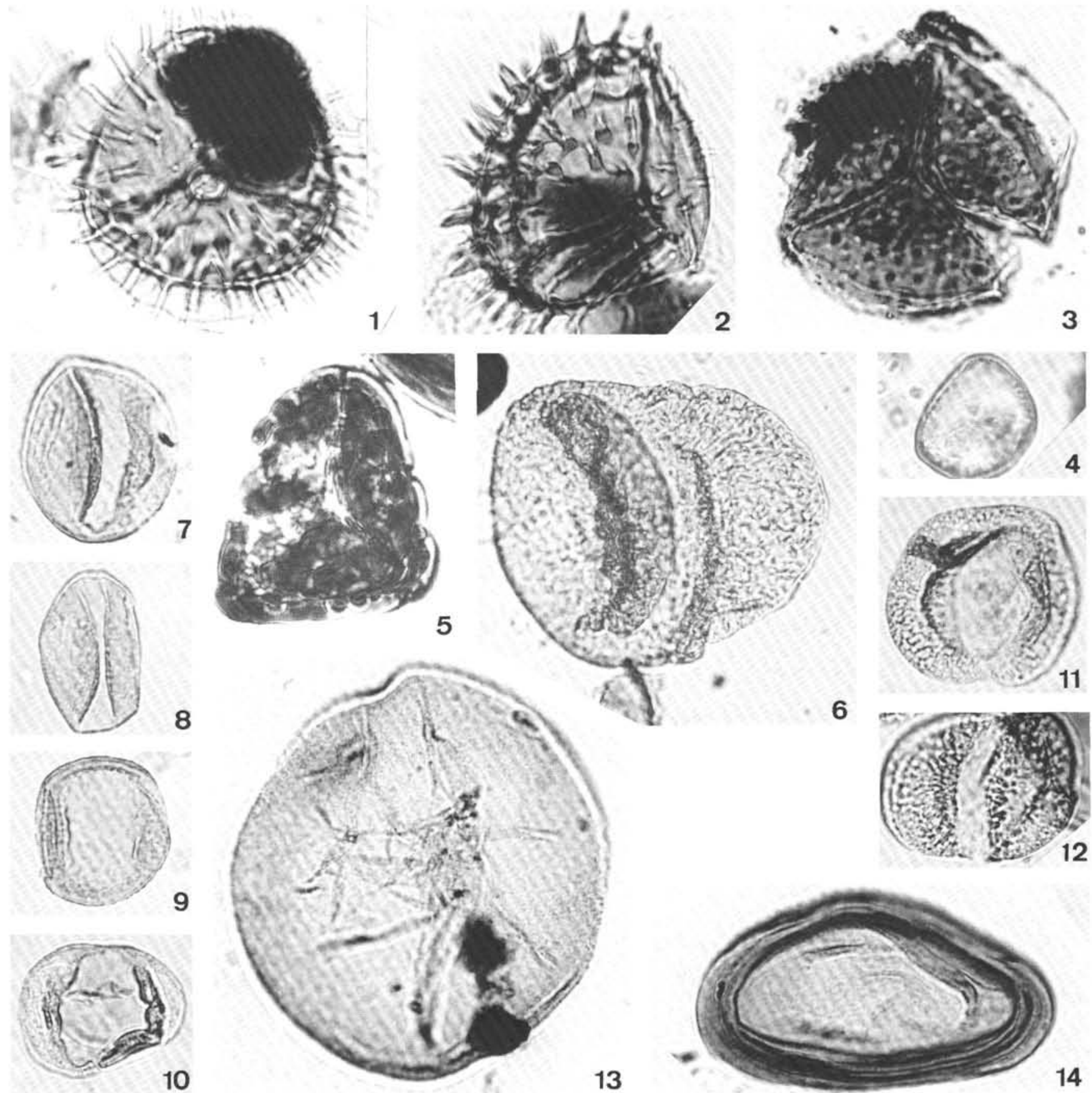

8

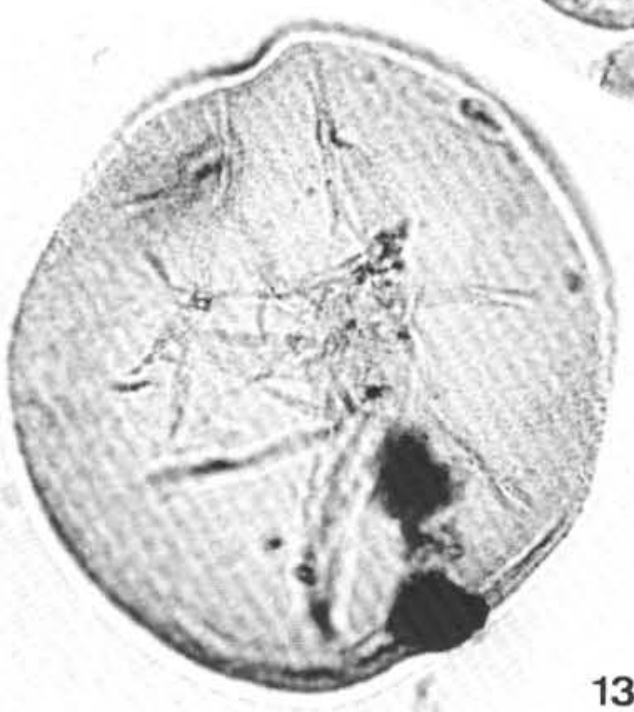

6
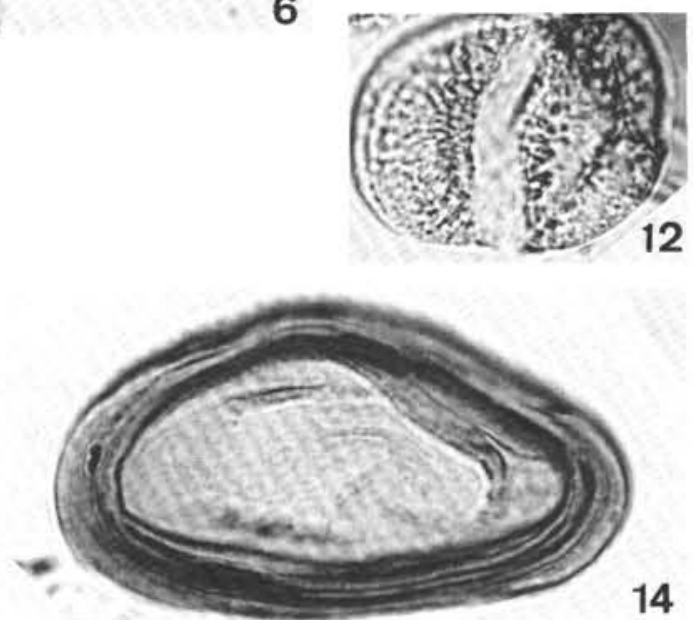

14

Plate 3. All magnifications $\times 1000$, unless otherwise specified. 1. Perotrilites linearis (Cookson and Dettmann, 1958) Evans, 1968; with membranous zona intact; Sample 120-750B-13W-1, 130-132 cm; sl. 2A, 44/91.2 (composite photo of a single specimen). 2. Perotrilites linearis (Cookson and Dettmann, 1958) Evans, 1968; with membranous zona mostly torn away; Sample 120-750B-13W-1, 130-132 cm; sl. 1A, 31.2/93. 3. Sestrosporites pseudoalveolatus (Couper, 1958) Dettmann, 1963; Sample 120-750B-14R-CC; sl. 1A, 44.5/90.5. 4. Stereisporites antiquasporites (Wilson and Webster, 1946) Dettmann, 1963; Sample 120-750B-14R-CC; sl. 2A, 38/93. 5. Trilites tuberculiformis Cookson, 1947; Sample 120-750B-14R-CC; sl. 1A, 39/92.2. 6. Alisporites similis (Balme, 1957) Dettmann, 1963; Sample 120-750B-13W-1, 130-132 cm; sl. 1A, 52/90.5. 7. Ashmoripollis woodywisei n.sp., holotype; Sample 120-750B-13W-1, 130-132 cm; sl. 4A, 37/88.5. 8. Ashmoripollis woodywisei n.sp.; Sample 120-750B-13W-3, 61-63 cm; sl. 1A, 33.2/82. 9. Ashmoripollis woodywisei n.sp.; Sample 120-750B-13W-1, 130-132 cm; sl. 1A, 46/87. 10. Ashmoripollis woodywisei n.sp.; Sample 120-750B-13W-1, 103-132 cm; sl. 1A, 46/82. 11. Sulcosaccispora alaticonformis (Malyavkina) de Jersey, 1968; Sample 120-750B-13W-1, 130-132 cm; sl. 2A, 43.2/94.2. 12. Vitreisporites pallidus (Reissinger, 1950) Nilsson, 1958, emend. de Jersey, 1964; Sample 120-750B-13W-1, 130-132 cm; sl. 1A, 49.5/86.5. 13. Balmeiopsis limbata (Balme, 1957) Archangelsky, 1979; Sample 120-750B-13W-1, 130-132 cm; sl. 4A, 37/88.5. 14. Balmeiopsis robusta Backhouse, 1988; Sample 120-750B-13W-1, 130-132 cm; sl. 2A, 44/88.2. 

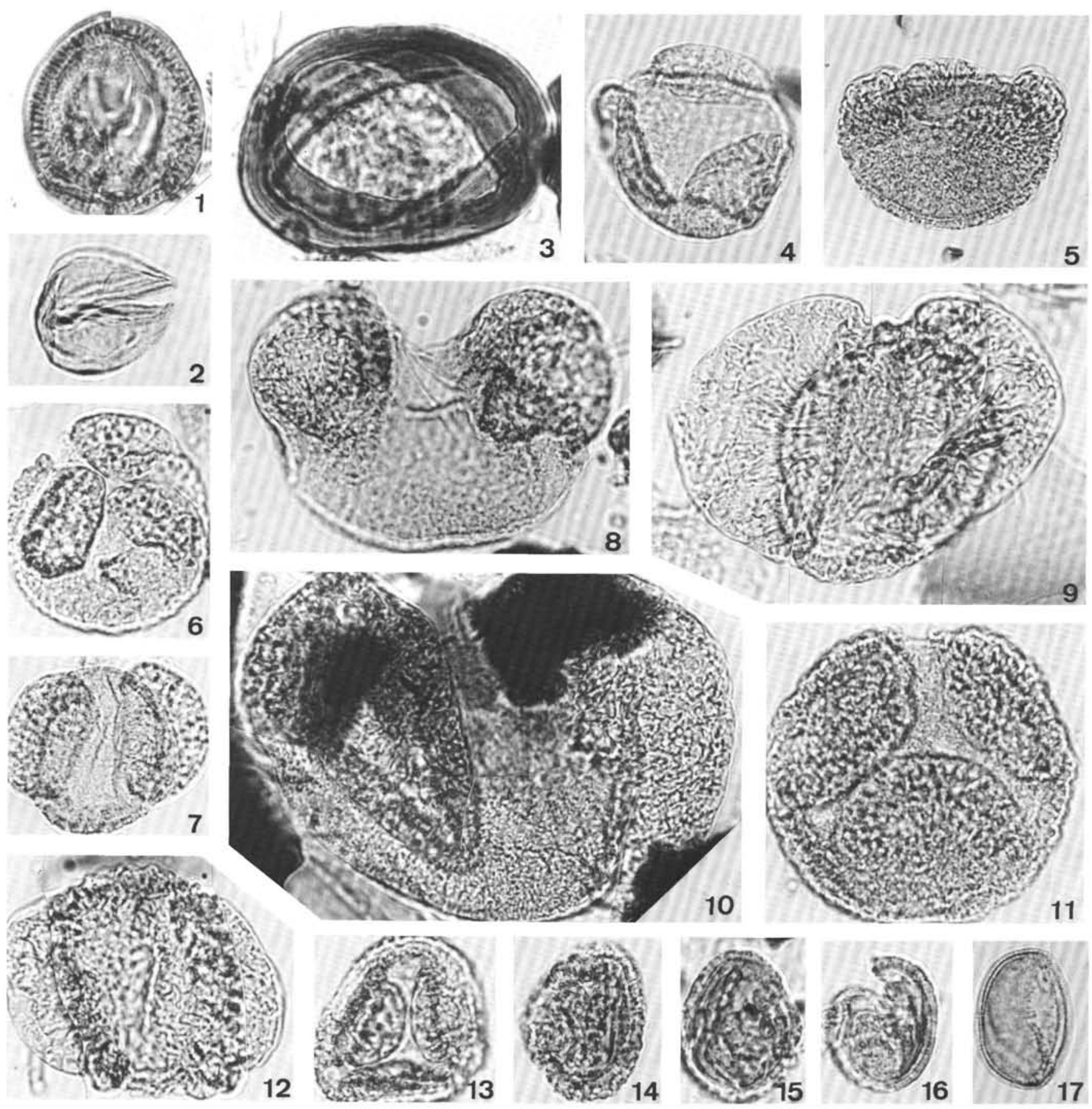

Plate 4. All magnifications $\times 1000$. 1. Corollina sp.; Sample 120-750B-13W-1, 130-132 cm; sl. 5A, $35.5 / 84.7$ (composite photo of a single specimen). 2. Cupressacites sp.; Sample 120-750B-13W-1, 130-132 cm; sl. 5A, 37/89. 3. Cyclusphaera psilata Volkheimer and Sepulveda, 1976; Sample 120-750B-13W-1, 130-132 cm; sl. 9A, 44.2/100. 4. Dacrycarpidites sp.; Sample 120-750B-13W-1, 130-132 cm; sl. 1A, 44/96.8. 5. Dacrydiumites florinii Cookson and Pike, 1953; Sample 120-750B-13W-1, 130-132 cm; sl. 1A, 35/102.2. 6. Microcachryidites antarcticus Cookson, 1947, ex Couper, 1953; Sample 120-750B-13W-1, 130-132 cm; sl. 1A, 35/84. 7. Microcachryidites parvus Couper, 1960; Sample 120-750B-13W-1, 130-132 cm; sl. 5A, 40.3/84.5. 8. cf. Pinuspollenites globosaccus (see Filatoff, 1975); Sample 120-750B-13W-1, 130-132 cm; sl. 9A, 31/93.5. 9. Podocarpidites ellipticus Cookson, 1947; Sample 120-750B-13W-1, 130-132 cm; sl. 4A, $49.5 / 90.5$ (composite photo of a single specimen). 10. Podocarpidites marwickii Couper, 1953; Sample 120-750B-13W-1, 130-132 cm; sl. 1A, $49 / 88.8$ (composite photo of a single specimen). 11. Podosporites castellanosii (Menéndez, 1968) Filatoff, 1975; Sample 120-750B-13W-1, 130-132 cm; sl. 1A, 44/81.8. 12. Rugubivesiculites sp.; Sample 120-750B-13W-1, 130-132 cm; sl. 5A, 47/83.5 (composite photo of a single specimen). 13. Trichotomosulcites subgranulatus Couper, 1953; Sample 120-750B-12W-CC; sl. 2A, 55.5/96.5. 14. ?Clavatipollenites sp.; Sample 120-750B-13W-1, 130-132 cm; sl. 1A, 33.2/84.5. 15. Clavatipollenites sp. A; Sample 120-750B-14R-CC; sl. 2A, 33.5/93.2. 16. Clavatipollenites sp.; Sample 120-750B-13W-1, 130-132 cm; sl. 3A, 41/92.5. 17. Clavatipollenites hughesii Couper, 1958; Sample 120-750B-13W-3, 51-63 cm; sl. 1A, 44.2/90. 